\title{
INTERAÇÃO ENTRE SUPRESSORES DE MUTANTES PARA DEFICIÊNCIA EM ÁCIDO NICOTÍNICO EM Aspergillus nidulans
}

\author{
CLAUDIO COSTA \\ IBBMA - UNESP \\ Campus de Botucatu
}

Orientador: Prof. Dr. JOÃO LÚCIO DE AZEVEDO

\begin{abstract}
Dissertação apresentada à Escola Superior de Agricultura "Luiz de Queiroz", da Universidade de São Paulo, para obtenção do título de Mestre em Genética e Melhoramento de Plantas.
\end{abstract}

PIRACICABA

Estado de São Paulo - Brasil

Junho - 1981 


\section{AO PRDFESSOR E ORIENTADOR}

DR. JOÃO LÚCIO DE AZEVEDO

TODO MEU CARINHO, RESPEITO.

E HOMENAGEM 
i i .

Aos meus pais

Ao Fábio, Maria Isabel

e Fảbio Henrique

D E D I C O 
i i i .

In memorian

Engo-Agro Demosthenes Santos Correa, meu Professor

Ruy Corbani dos Santos Caio, meu Amigo 


\section{BIOGRAIA}

CLAUDIO COSTA, filho de Natalino costa e valentina Visockas Costa.

Engenheiro-Agrônomo formado pela Escola Superior de Agricultura "Luiz de Queiroz", da Universidade de São Paulo, em 1972.

Foi probessor de Genētica da Fundação Faculdade de Agronomia "Luiz Meneghel", de Bandeirantes, Paranā. Atualmente pertence ao Departamento de Genética do Instituto Bāsico de Biologia Médica e Agrícola, da Universidade Estadual Paulista "Julio de Mesquita Filho", campus de Botucatu, SP. 
Agradeço a todos que de uma forma ou de outra contribuiram para que pudesse realizar este trabalho. De maneira especial quero agradecer:

- Ao Prof. Dr. João Lúcio de Azevedo, mestre, orientador e amigo.

- Ao Prof. Dr. Ernesto Paterniani, pelas facilidades concedidas como Diretor do Instituto de Genética e chefe do De partamento de Genética da E. S. A. "Luiz de Queiroz", da Universidade de São Paulo, e pelo apoio e confiança recebidos.

- Ao Prof. Dr. Gilberti Moreno, atual Diretor do Instituto Básico de Biologia Médica e Agrícola do campus de Botucatu e a Profa. Wilma Pereira Bastos Ramos, ex-Diretora do IBBMA, pelo apoio e facilidades concedidas.

- Ao Prof. Dr. Ademar Freire-Maia, ex-chefe do Departamento. de Genética do IBBMA e Profa. Dra. Dertia V. Freire-Maia, atual chefe, pela confiança e amizade.

- A Sra. Carlota Rensi Meneghel, da Fundação Faculdade de A gronomia "Luiz Meneghel", de Bandeirantes, Paraná, pelo in centivo, amizade e apoio na fase inicial deste trabalho.

- A Dra. Lorna A. Casselton, da Universidade de Londres, pe las sugestões apresentadas. 
- Aos colegas do curso de Pós-Graduação, pela amizade e carinho.

- Aos colegas do Departamento de Genética do IBBMA, pela amizade .

- Aos funcionários do Instituto de Genética da EsALQ/USP, principalmente aos do Setor de Microrganismos, pela amiza de, carinho, colaboração e assistência prestadas.

- Aos funcionários do Departamento de Genética do IBBMA, campus de Botucatu, pela colaboração dada.

- A Drá. Yoko Bomura Rosato, da Universidade Estadual de Cam pinas, pelo apoio.

E DE MANEIRA MAIS ESPECIAL O MEU MUITO OBRI GADO AOS PROFESSORES DR. CARLOS ALBERTO DE MAGALHÃES LOPES, CHEFE DO DEPARTAMENTO DE MI CROBIOLOGIA E IMUNOLOGIA DO IBBMA E DR, GIL BERT I MORENO, EX-CHEFE, DEMAIS PROFESSORES E FUNCIONÁRIOS DO REFERIDO DEPARTAMENTO, PELA AMIZADE, CARINHO E VERDADEIRO ESPÍRITO DE COOPERACÃO CIENTIIFICA, EM ME PERMITIR O USO DE SEUS LABORATÓRIOS E EQUIPAMENTOS, SEM OS QUAIS NÃO TERIA CHEGADO AO TÉRMINO DESTE TRE BALHO , 
vii.

I $\mathbf{N} \quad \mathbf{D} \quad \mathbf{I} \quad \mathbf{C} \quad \mathbf{E}$

Pàg .

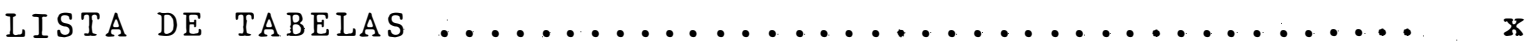

LISTA DE FIGURAS $\ldots \ldots \ldots \ldots \ldots \ldots \ldots \ldots \ldots \ldots \ldots \ldots \ldots \ldots \ldots \ldots \ldots$

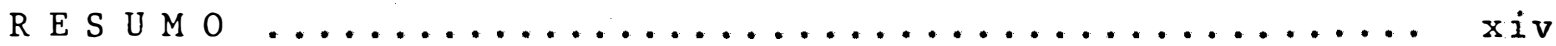

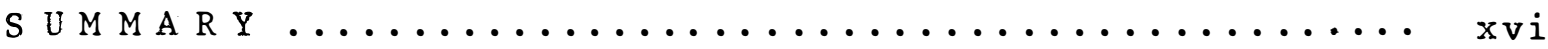

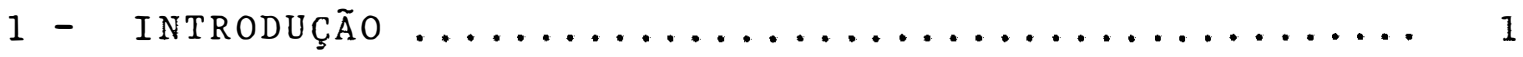

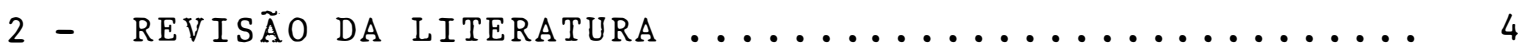

2.1 - Considerações Gerais sobre Supressão Gênica. 4

2.2 - Supressores Indiretos (Intergênicos) ...... 9 9

2.3 - Supressores Diretos (Intragênicos) ...... 19

2.4 - Supressores de Informação ............. 22

2.5 - Principais Aspectos da Supressão Gênica em Aspergillus nidulans envolvendo o ge

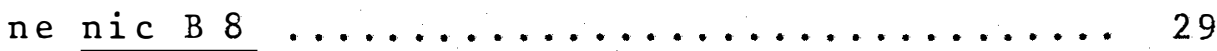

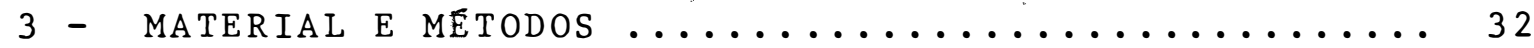

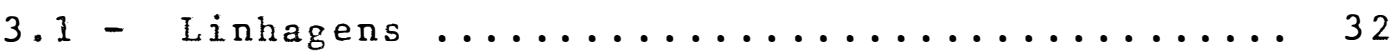

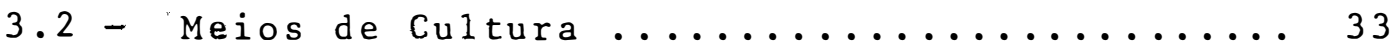

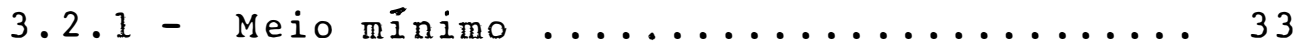

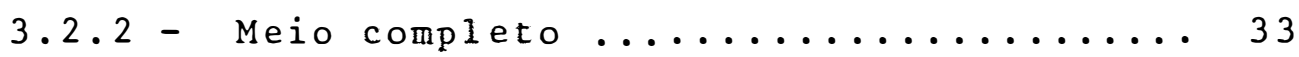

3.2 .3 - Meio de galactose .................... 37 
viii.

Pág •

3.2 .4 - Meio de acetato de amônio ........ 37

3.2 .5 - Meio minimo líquido mais $2 \%$ de meio

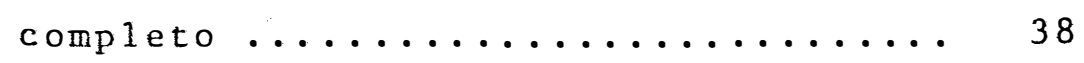

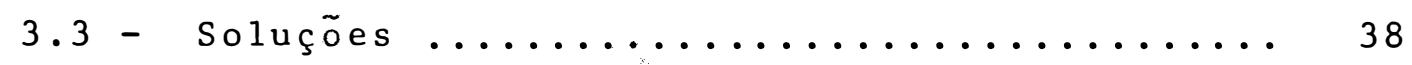

3.3 .1 - Solução de vitaminas ........... 38

3.3 .2 - Solução de àcido nucléico de levedura 38

3.3 .3 - Solução de Tween ............... 39

3.3 .4 - Solução salina .................. 39

3.3.5 - Suplementos adicionados ao meio mí-

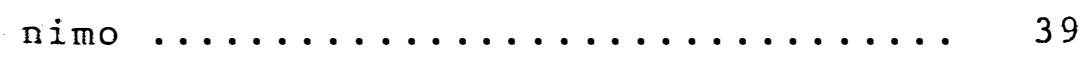

3.3 .6 - Placas de anālise ............. 40

3.4 - Esterilização e Incubação ............. 40

3.5 - Técnicas de Anālise Genética .......... 41

3.5 .1 - obtenção de heterocários ........4 41

3.5 .2 - Anālise meiótica ............ 41

3.5 .3 - Anālisemitótica ............ 42

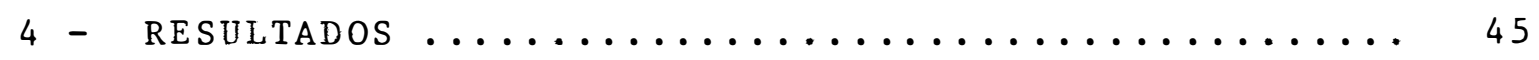

$4.1-$ Cruzamentos Controle ............... 45

4.1 .1 - Resultados de cruzamentos de linha gens com supressores e linhagem $\underline{\text { pro A } 1}, \underline{\text { paba A } 6} ; \underline{\text { yA } 2} \ldots \ldots \ldots \ldots 45$

4.1 .2 - Anālise meiótica ............ 46

$4.1 .3-$ Anālise mitótica .............. 46

4.1 .4 - Cruzamento da 1 inhagem MSE com a

1 inhagem pro A 1_; paba A 6 : yA 2 $\ldots 49$ 
4.1.5 - Resultados de cruzamentos entre a linhagem $\underline{\text { y A 2 }}$; nic A 2 ; ribo D com a linhagem bi A 1 ; meth G 1 ... 51

4.1.6 - Anālise de heterocários e diplóides. 51

4.2 - Testes de Especificidade ............ 53

4.3 - Cruzamentos de Linhagens com Genes Su pressores e Outras Linhagens .......... 55

4.3.1 - Cruzamentos das 1 inhagens com genes supressores e a linhagem pyro

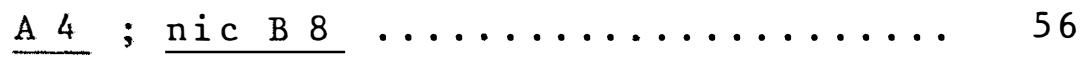

4.4 - Análise dos Segregantes que Possivelmente Continham Dois Supressores para a mes

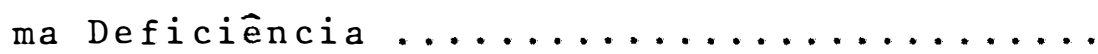

4.5 - Heterocārios e Diplóides entre Linhagens Provavelmente Portadoras de Dois Genes Su

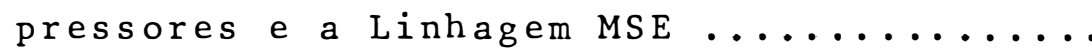

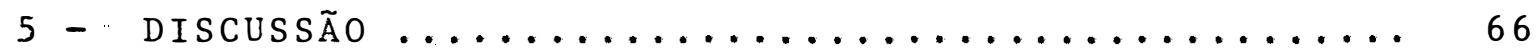

$5.1-$ Cruzamentos Controle ................ 66

5.2 - Testes de Especificidade ............. 68

5.3 - Comportamento de Dois Supressores Reunidos na Mesma Linhagem ................ 71

5.4 - O Mecanismo de Ação dos Supressores ...... 75

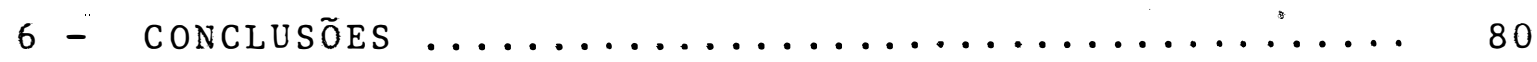

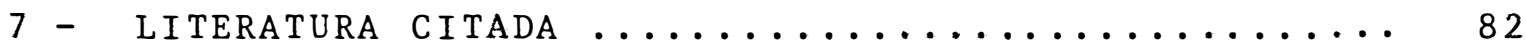




\section{LISTA DAS TABELAS}

TABELA 1 - Lista das Iinhagens de AspergizZus nidulans utilizadas neste trabalho com seus respectivos marcadores genéticos e

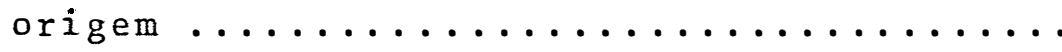

TABEla 2 - Lista dos loci gênicos das linhagens de Aspergizzus nidulans utilizadas neste trabalho com seus respectivos símbolos, fenótipos e grupos de 1 igação ...........

TABELA 3 - Substâncias adicionadas aos meios de

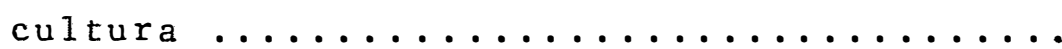

TABELA 4 - Resultados dos cruzamentos entre linha gens portadoras de genes supressores e a linhagem pro A 1 paba A 6 ; yA $2 \ldots$

TABELA 5 - Segregação meiótica do cruzamento das linhagens supressoras com a linhagem proA 1 ; paba A 6 ; yA $2 \ldots \ldots \ldots$

TABELA 6 - Resultados da anālise mitotótica de sẹ tores haplóides obtidos de diplóides MSE su nic B 8// pro A 1 ; paba A 6 ;

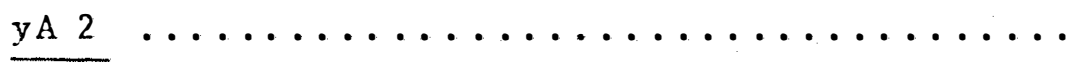

TABELA 7 - Anālise meiótica do cruzamento da 1inhagem MSE com a linhagem pro A 1 ; paba A $6 ;$ yA $2 \ldots \ldots \ldots \ldots \ldots \ldots \ldots \ldots \ldots \ldots \ldots \ldots \ldots$ 
TABELA 8 - Resultados do cruzamento entre as 1inhagens biA 1 ; meth G 1 e yA 2 ;

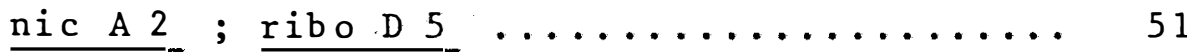

TABELA 9 - Heretocários e diplóides entre as 1inhagens com supressores e a linhagem $33 \ldots 52$

TABELA 10 - Resultados dos cruzamentos entre as 1 i nhagens portadoras de genes supresso res e a 1 inhagem yA 2 ; nic A 2 ; ribo D 5. 54

TABELA 11 - Resultados de cruzamentos entre linhagens com genes supressores e o segre gante 13 (su 8 nic B 8 ; pyro A 4 ; pa

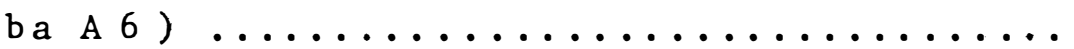

TABELA 12 - Cruzamentos entre as linhagens su ni B 8 e segregante su 3 nic B 8 x $33 \ldots \ldots . \ldots 58$

TABELA 13 - Cruzamentos entre os descendentes de su $2 \times$ su $3(301$ e 304$)$ com bi Al;

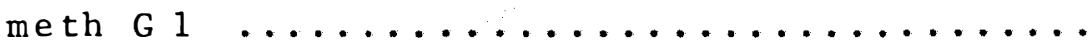

TABELA 14 - Cruzamentos entre os descendentes de su 5 su 3 . (304 e 319) com bi Al ; meth $\mathrm{m}_{1} \ldots \ldots \ldots \ldots \ldots \ldots \ldots \ldots \ldots \ldots$

TABELA 15 - Cruzamentos entre os descendentes de su 8 x su 3 ( 304 e 309$)$ com bi Al ; meth.G $1 \ldots \ldots \ldots \ldots \ldots \ldots \ldots \ldots \ldots \ldots \ldots \ldots \ldots \ldots \ldots$ 
xii.

Pàg.

TABELA 16 - Heterocários e diplóides entre linhagens provavelmente portadoras de dois genes supressores e a 1 inhagem MSE ...... 
xiii.

\section{LISTA DE FIGURAS}

Pàg.

FIGURA 1 - Mapa parcial de ligação de Aspergizzus

nidulans com os marcadores genéticos u

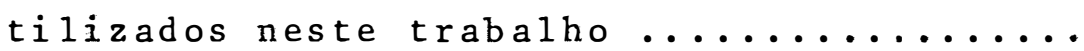

FIgURA 2 - Sistema de regulação em cascata ......... 76

FIGURA 3 - Sistema alternativo de regulação em cas

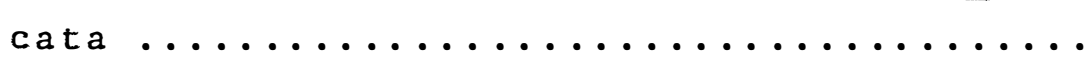




\title{
INTERAÇAO ENTRE SUPRESSORES DE MUTANTES PARA DEFICIENCIA EM ACIDO NICOTINICO EM Aspergizzus niduzans
}

\author{
CLAUDIO COSTA
}

Prof. Dr. João Lūcio de Azevedo orientador

RESUMO

0 presente trabalho teve como objetivo o estudo da interação entre genes supressores para deficiēncia em àcido nicotínico em Aspergizzus niduzans. Foram estudadas a ação de especificidade dos supressores do mutante nic B 8 e o comportamento de linhagens nos quais foram reunidos dois supressores para a mesma deficiēncia.

Para se observar se os supressores do mutante nic B 8 em estudo eram especificos ou não, foram feitos cruza mentos e heterocārios entre linhagens contendo 0 supressor nic B 8 e linhagens contendo o mutante nic A 2. 0 supressor nic B 8 mostrou ser específico em sua ação não suprimindo o mutante nic A 2 .

Para se observar o comportamento de dois supres sores reunidos na mesma linhagem, foram feitos cruzamentos en 
tre as linhagens MSE su nic B 8 e outras linhagens contendo 0 mutante nic B 8. Os segregantes que exibiram prototrofia pa ra o ācido nicotinico foram cruzados com as linhagens iniciais portadoras dos supressores.

Foi observado que segregantes que provavelmente continham dois supressores reunidos na mesma linhagem mantiveram seu efeito de supressão.

0 sistema de regulação em cascata e a presença de tRNA alterados foram propostos para explicar o modo de ação dos supressores. 
INTERACTIONS BETWEEN NICOTINIC ACID SUPPRESSORS IN

Aspergizlus nidulans

\author{
CLAUDIO COSTA \\ Prof. Dr. João Lúcio de Azevedo \\ Advisor
}

SUMMARY

The purpose of this paper is the study of the ability of some supressor genes of the nic B 8 mutation in Aspergizzus niduzans in suppress other nicotinic acid deficien cy genes and the suppression effect of two nic B 8 suppressor carrying strains.

It was shown that nic B 8 suppressor genes are gene specific. They don't suppress any other nic mutation. The supression effect is suposed to be maintened in two nic B 8 suppressor-carrying strain.

The cascade regulation system in addition to altered tRNA were applied to explain the suppression action mode. 


\section{1 - INTRODUÇÃO}

Mutações supressoras são mutações secundārias que modificam o fenótipo em presença do gene mutante original. E o desaparecimento do fenótipo mutante através da ocorrência de uma segunda mutação que pode se dar no mesmo gene ou noutro gene qualquer.

Os supressores podem ser separados dos genes mu tantes originais através da recombinação genética.

Stutervant em 1920, foi quem utilizou pela pri meira vez o termo supressão referindo-se ao desaparecimento do fenōtipo mutante atravēs de mutação em gene distinto ao gene da mutação original (apud: Gorini e Beckwith, 1966).

Sob ponto de vista mais atualizado podemos dizer que supressão gēnica se refere ao desaparecimento do fenō tipo mutante através de mutação em sitio diferente do sitio da mutação original. 
GORINI e BECKWITH (1966) classificaram os supressores gênicos em duas grandes classes, diretos e indire tos, sendo ainda a primeira classe dividida em supressores in tragēnicos e de informação.

No conceito de supressores também incluem-se ge. nes que impedem a manifestação de outros genes. Isto viria a explicar certos casos de diferenciação sexual e diferenciação celular no processo de desenvolvimento de organismos superio res.

Além de desempenharem importante papel na atividade biológica dos organismos os supressores também são cau sa de variabilidade genētica.

Os genes supressores podem causar nos microrga nismos variações de maior valor adaptativo e no caso de micror ganismos patogénicos podem resultar em consequēncias de grande importāncia.

o valor do estudo da supressão gênica estā hoje solidamente estabelecido e intensivos estudos vêm sendo desenvolvidos no sentido de se determinar e esclarecer os mais variados aspectos desse fenōmeno biológico.

Um desses aspectos se relaciona à problematica da regulação gēnica interrelacionada com supressão.

Em 1963 PONTECORVO descreveu um sistema de regulação génica, designado sistema de regulação em cascata, on de vārios genes reguladores estavam supostamente presentes. 
0 sistema se prestava bem para explicar a ocorréncia de certos fenómenos em eucariotos, especialmente em fungos filamen tosos. Certos aspectos do modo ação de alguns genes supresso res poderiam ser explicados por esse sistema.

Os estudos de supressão gênica envolvendo a mar ca genētica nic B 8 do fungo Aspergizzus niduzans iniciaramse em 1965 com o trabalho de WARR e ROPER.

Um estudo posterior de mutantes supressores do gene nic B 8 em Aspergizzus niduzans, realizado por MIRANDA FILHO e AZEVEDO (1974), produziu resultados que tentativamente foram explicados pelo sistema de regulação em cascata. No entanto, para maior compreensão dos sistemas de supressão para deficiēncia em àcido nicotínico, mais dados genēticos teriam de ser introduzidos, tais como obtenção de um nūmero maior de supressores, o estudo da especificidade do locus nic B 8 e a introdução de mais um gene supressor em linhagens já portadoras de um supressor do locus nic B 8 .

A obtenção de um nümero maior de supressores bem como um estudo dos mesmos foi conduzido, concomitantemente ao presente trabalho, por MONTEIRO (1979).

Então, os objetivos destas pesquisas foram estudar a especificidade de alguns supressores do gene nic B 8 em Aspergizzus niduzans bem como verificar o modo de ação de mais de um gene supressor atuando no locus nic B 8 em uma me ma I inhagem. 


\section{2 - REVISÃO DA LITERATURA}

\section{1 - Consideracões Gerais sobre Supressão Gênica}

0 termo supressão, como jā visto anteriormente,

é um termo utilizado por geneticistas para se referir a qualquer mutação que mascara o efeito de outra mutação no mesmo gene ou em qualquer outro local do mesmo complemento cromossōmico.

Os primeiros casos de supressão gēnica foram interpretados por MORGAN e colaboradores (1925) e SCHULTZ e BRIDGES (1932, apud HARTMAN e ROTH, 1973) como duplicações gê nicas. Posteriormente outros autores como BONNIER (1927), PLOUGH (1928), BRIDGES (1932), SCHULTZ e BRIDGES (1932, apud HARTMAN e ROTH, 1973) mostraram que supressão gênica podia ser resultante da interação de genes não alélicos. 
HAWTHORNE E LEUPOLD (1974) consideram, entretan to, que os casos de supressão intragênica, isto é, aqueles em que a segunda mutação ocorre em outro local do mesmo gene mutante original, podem levar a um uso incorreto do termo "supressão". Observam os autores que supressão deveria ser utilizada somente para os casos de mutação intergênica.

Evidēncias bioquĩmicas hā de que a supressão é a restauração de uma função que o organismo originalmente pos suia e dentre os primeiros trabalhos que tentaram mostrar os mecanismos bioquímicos que levam à supressão destaca-se o de BEADLE e EPHRUSSI (1936, apud: GORINI e BECKWITH, 1966).

Estes autores demonstraram que um supressor recessivo e alelo específico do gene $\underline{v}$ (cor "vermillion" do olho de Drosophila) era capaz de restaurar parcialmente a capacidade do indivíduo mutante em produzir cinurenina, uma substāncia exigida para de senvolvimento da coloração tipo selvagem do olho.

Em vista disso podemos observar que hā grande variedade de relações entre os genes supressores e os alelos que suprimem.

Assim, um supressor pode ser estritamente ale10-específico, isto é, suprime mutações que ocorrem num codon particular dentro de um gene ou ser igualmente capaz de supri mir muitas (ou mesmo todas) mutações que ocorrem em diferen tes codons dentro do mesmo gene, ou ainda, mutações do mesmo codion ocorrendo em genes não relacionados. 
De acordo com seu modo de ação os supressores podem atuar das maneiras que se seguem:

1 - A segunda mutação pode ser num gene cujo produto abre uma via metabólica alternativa. Por exemplo, como resultado de uma segunda mutação pode surgir uma enzima que permita a sintese de um produto intermediārio cuja sintese, a travēs da via metabólica normal, estava interrompida pe1 a primeira mutação.

2 - A segunda mutação pode ser num gene cujo produto possa substituir diretamente a função do produto do primeiro gene. Por exemplo, a segunda enzima (ou proteina) pode mu tar de modo a apresentar uma especificidade ou função maio res abrangendo as propriedades perdidas pelo produto da primeira mutação.

3 - A segunda mutação proporciona condições citoplasmáticas, tais que venham afetar a estrutura do produto final do primeiro gene mutado. Por exemplo, esta nova condição pọ de estabilizar uma enzima que, por apresentar mudanças em sua estrutura, seja instāvel no meio citoplasmātico original.

4 - A segunda mutação introduz uma segunda alteração dentro da mesma cadeia peptídica (segunda substituição de amino ácido) que restaura, completa ou parcialmente, a função proteíca, com reaparecimento do fenótipo selvagem ou qua se selvagem. 
5 - A segunda mutação reintroduz o modo correto de leitura dentro do mesmo gene cuja sequēncia de codons fora alterada por adição ou deleção de um par de bases.

6 - A segunda mutação atua num dos fatores que controlamo me canismo de transferēncia da informação genética a partir do àcido desoxirribonucléico (DNA) até a proteina.

Há diferenças básicas, como se pode observar entre os trés primeiros e os três ūltimos grupos de mecanismos de supressão gènica.

0 primeiro grupo de supressores atua claramente de maneira indireta para contornar o problema. São os genes supressores indiretos.

0 segundo grupo inclui os genes supressores di retos, onde a segunda mutação resulta numa correção de maneira direta do produto do gene alterado pela primeira mutação. (GORINI e BECKWITH, 1966).

0 grupo de supressores diretos por sua vez pode ser subdividido em duas classes diferentes. Aqueles cujos mecanismos de ação se relacionam com os ítens 4 e 5 , são chamados "supressores intragēnicos". Os supressores cujos mecanismos de ação são do tipo descrito no item 6 são os chamados "supressores de informação".

Por definição os supressores de informação são sempre intergénicos e podem atuar em qualquer um dos passos $\underline{\text { re }}$ lativos à transferēncia de informação do DNA à proteina. RINI, 1970). 
Entre os supressores de informação incluem - se aqueles que se relacionam à estrutura dos ribossomos. Os ribossomos têm importante papel na manutenção da fidelidade do pareamento codon-anticodon. Então não è de se causar surpre sas que alterações na estrutura dos ribossomos possam causar erros no pareamento levando à supressão. Estes supressores têm o nome especial de supressores fenotípicos (CASSELTON, $1971)$

o estudo da supressão gēnica evoluiu de tal ma neira nos ūltimos anos que se conduziu à necessidade de se es tabelecer uma nomenclatura unificada devido ao crescente nūme ros de supressores caracterizados. As revisões de GORINI (1970) e HARTMAN e ROTH (1973) estabelecem os critērios para designa ção e uso de símbolos em supressão.

Novos aspectos do fenōmeno de supressão vêm sen do relatado pelos pesquisadores, destacando-se a super-supres são e anti-supressão.

Mutações super-supressoras são mutações capazes de reverter simultaneamente o fenōtipo de duas mutações $\underline{0}$ riginais independentes. Maiores detalhes sobre este aspecto da supressão podem ser encontrados no trabalho de MONTEIRO $(1979)$

Os anti-supressores são genes mutantes que exi bem ação antagonista em reḷção ao supressor. Geralmente diminuem o nīvel de supressão ao inv̄es de inativar completamente o supressor. 
Autores como McCREADY e $\operatorname{COX}(1973,1976)$ descreveram anti-supressores em leveduras e PICARD-BENNOUM (1976) e COPPIN-RAYNAL (1977) observaram estes genes em Podospora an serina. As evidēncias genēticas sugerem que muitos dos genes anti-supressores estejam relacionados a mutações ribossomais restritivas. (MONTEIRO, 1979).

cox (1977) observou tambēm a presença de uma outra classe de genes relacionados ao fenómeno da supressão, aos quais deu o nome de alossupressores. São genes mutantes recessivos que permitem um aumento no nĩvel de supressão. Na levedura saccharomycés cerevisae os produtos gēnicos dessas mutações provavelmente estariam envolvidos nos processos de tradução a nível ribossōnico.

Faremos em seguida uma revisão dos principais trabalhos envolvendo aspectos de supressão direta, indireta e de informação em diversos organismos procariotos e eucariotos. Aspectos de supressão para àcido nicotínico envolvendo o fungo ascomiceto Aspergizzus niduzans serão observados num item particular.

\section{2 - Supressores Indiretos (InTERGĒNicos)}

A partir da década de 1950 as anālises bioquĩmicas associadas às técnicas de anālise genética envolvendo mí crorganismos procariotos e eucariotos e eucariotos superiores 
vieram aclarar uma série de mecanismos de supressão indireta. Podemos, entre outros, citar os trabalhos de WAGNER e MITCHELL (1955, 1964) ; YANOFSKY e ST. LAWRENCE (1960) ; CAMPBELL (1963), e as revisões de GORINI e BECKWITH (1966) ; GORINI (1970) ; CASSELTON (1971) e HAWTHORNE e LEUPOLD (1974).

HOULAHAN e MITCHELL (1947) demonstraram, pela primeira vez, a ocorrencia de supressores em Neurospora. Uti lizaram mutantes deficientes para pirimidina (mutantes pyr 3 ) e mostraram interações do supressor com diversos mutantes pyr.

MITCHELL e MITCHELL (1952) mostraram que o supressor de pyr em Neurospora influenciava a manifestação de outros genes, principalmente para auxotrofia.

BONNER (1951) estudando em Neurospora o proble ma da supressão para deficiēncia em triptofano observou que no mutante 2198 o gene supressor se mostrava especifico em seu efeito, isto é, não era capaz de suprir a deficiēncia para triptofano em outras linhagens.

Usando tambēm Neurospora como material de estudos, GILES (1951) e GILES e PARTRIDGE (1953) observaram a ocorréncia de genes supressores para metionina e inositol. Um dos mutantes met foi capaz de suprimir outro mutante diferente, mostrando com isso uma ação não específica, restabelecendo uma via metabólica alternativa, pois a original estava blo queada pelo primeiro mutante. 
LEIN e LEIN (1952) obtiveram um supressor numa I inhagem de Neurospora deficiente em acetato e testaram-no em outras duas visando demonstrar o efeito de um mesmo supressor em genes não alelos. Seu efeito foi comprovado nas linhagens testadas.

HOWART (1958) detectou vārios supressores do mutante cys (deficiència para cistina) em salmonezza typhimurium. Verificou que todos os supressores eram não-especĩficos, capazes de suprimir diversos mutantes. Considera tamoem que provavelmente agem pela introdução de uma via metabólica alternativa.

LEWIS (1961) obteve sete diferentes genes controlando passos metabōlicos para sintese de metionina no fungo basidiomiceto Coprinus Zagopus. Estudando a prototrofia por reversão, observou que as linhagens que carregavam os genes me-1 e me-7 revertiam espontaneamente numa taxa maior e que essa reversão era devida a genes supressores e não propria mente mutação reversa. Num estudo intensivo de 64 mutantes de origens independentes que suprimiam o mutante me-1, observou que haviam cinco loci supressores. Efetuando testes de complementação, concluiu que eram todos recessivos em relação ao selvagem e que mutantes no mesmo locus não se complementavam. Mutantes em loci diferentes se complementaram em dicarios na posição trans. Observou tambēm que sup 3 e sup 4, indepen dentes de sup 5 não se complementaram com este ültimo gene em estudo. 
DAVIS (1961, 1962) estudando genes supresso res para arginina em Neurospora verificou que o mutante pyr 3-a. deficiente em pirimidina é suprimido pelo mutante arg 12-s. A mutação arg 12-s tem o efeito de diminuir drasticamente o nível de ornitina transcarbamilase, que é a enzima que utiliza carbamil fosfato para a biossintese de arginina.

Num estudo posterior REISSIG (1963.a e 1963.b), verificou que o mutante arg 2, deficiente em arginina em Neu rospora, bloqueado antes da ornitina transcarbamilase mostrou ser suprimido pela introdução da pyr-3d. A mutação pyr-3d. elimina a atividade da aspartato transcarbamilase. Este tipo de padrão de supressão pode ser explicado, supondo-se, que em Neurospora, hajam dois conjuntos de carbamil fosfato independentemente sintetizados, carbamil fosfato pyr e carbamil fosfato arg. Uma mutação evitando a sintese do conjunto precedente pode ser suprimida por uma mutação que desvia o conjunto posterior para a via metabólica da pirimidina e vice-versa.

LILLY (1963) trabalhando com Aspergizzus niduZans observou que os mutantes meth 1. deficientes em metioni na, eram capazes de serem suprimidos por genes supressores e pecíficos e não ligados ao locus mutante.

MORGAN (1966) estudando reversões espontāneas de mutantes pūrpura para branco em Coprinus Zagopus, demons trou que eram devidas à supressão. Quarenta e uma das cinquen ta linhagens pūrpura que tinham seu efeito suprimido foram cruzadas com o tipo selvagem e em todos os cruzamentos surgi - 
ram menos que $25 \%$ de descendentes pūrpura mostrando que os su pressores deveriam estar ligados aos genes que suprimiam. As relações funcionais desses supressores foram analisadas pela técnica de complementação em dicārios e os resultados mostraram que dois loci supressores exibiam complementação inter-alēica extensiva.

CHILDS (1967) constatou diversos supressores em linhagens deficientes para metionina em Salmonezza typhimurium e diferenciou supressores com e sem especificidade para deter minadas mutações met $B$.

WEGLENSKI (1966, 1967) e PIOTROWSKA, SAVICKI, e WEGLENSKI (1969) estudaram supressores da deficiēncia em prolina em. Aspergizzus niduzans. Observaram e mapearam trés supressores (su 2,$\underline{\text { su } 6}$ e su 19) e verificaram serem do tipo intergènico. No entanto, cada um exibiu um modo específico de ação, apesar de todos em comum afetarem a sintese ou degra dação de arginina de modo a permitir a sintese de prolina atravēs de um processo alternativo, diferente do usual.

GAJEWSKI e LITWINSKA (1967) estudando reversões espontāneas de alguns mutantes deficientes para metionina em Aspergizzus niduzans observaram que estas reversões eram devi das à supressão. Os supressores mostraram ser parciais ou to talmente recessivos. Analisando o mutante meth B observaram, que o supressor $\underline{r} 2$ era não específico e o $\underline{r} 3$ era altamente específico para o locus em questão: 
STADLER (1967) estudando mutantes mtr (resistentes a metil-triptofano e p-fluorofenilalanina) em Neurospo ra verificou a presença de supressores não específicos para 0 locus mtr (eram capazes de suprimir qualquer mutante mtr).

AYLING (1969) estudando supressores do locus meth B s em Aspergizzus niduzans encontrou seis loci supressores daquele mutante. Verificou que alguns dos supressores foram dominantes no heterocārio, mas recessivos no diplóide. Considera tambēm o autor que o sistema de supressão do gene meth B 3 seja bastante complexo, em vista do grande nümero de supressores detectados.

o fenōmeno da super-supressão é, na maior partee das vezes, devido a ação intergênica, sendo classificado como supressão indireta. Em outros casos, super-supressão ocorre devido à ação combinada de supressores diretos, indiretos e de informação.

CHALMERS e SEALE (1971) analisaram mutantes 28 tryp 2 e 13 tryp 1 que afetam a estrutura de um complexo multienzimātico em Neurospora, relacionados à via metabólica da biossintese do triptofano. Observaram o fenōmeno de supersupressão devido à presença de quatro super-supressores, sendo que seis dos mutantes tryp 2 e dois dos mutantes tryp 1 mostraram efeito de supressão, tanto pelos aspectos genéticos quanto bioquímicos da questão. Consideram que os fenótipos ex tremos exibidos pelos mutantes tryp l e tryp 2 são devidos a terminaçōes prematuras das cadeias protéicas dos complexos en 
zimáticos, pela ocorrēncia de codons de ponto final. Os supressores de codons de ponto final de cadeias protéicas podem se apresentar como alelo específicos, isto é, ou não suprime todos os mutantes desse dado locus ou não restaram a atividade de todos mutantes "nonsense", que são os mutantes que apre sentam um ponto final que interrompe prematuramente a cadeia proteica los trés codons de ponto final são UAG, UGA e $(A A)$.

cox (1971) observou que um super-supressor em leveduras, relacionado a codon UAA (ochre), que é terminalizador de cadeias protéicas, era um gene letal recessivo, como pode comprovar através de anālises genéticas. Observou também que o fenótipo letal poderia ser perdido sem que se per desse o fenótipo de supressão. Este fato era devido à presen ça de um fator citoplasmático denominado psi. o supressor

$\underline{\text { SQ } 2}$ era letal em linhagens haplóides $\underline{\mathrm{ps}^{+}}$mas não em linhagens psi-. Este determinante citoplasmático fora previamente identificado pelo fato de modificar a atividade de outro su per-supressor específico para o codon UAA (ochre). Nesse caso era o fenótipo de supressão que era modificado. Nas linha gens psi- as mutações de codon UAA (ochre) não eram suprimi das pelo supressor $\underline{S Q 5}$, enquanto que as linhagens $\underline{p^{+}}+$eram suprimidas.

YOUNG e COX (1971) estudando supressores para deficiēncia em adenina em leveduras, encontraram super-supres sores em $90 \%$ dos revertentes do locus ade 2-1. 0s mutantes 
ade 2-1 foram obtidos espontaneamente de linhagens revertentes Adet. A linhagem carrega um super-supressor específico para mutantes ochre (UAA) e pode ser inativado em presença de uma mutação extracromossómica que ocorre no fator psi.

CHANG (1972) observou a ocorrência de supres sores em Schizophylum commune. Analisando geneticamente o mutan te denominado "dome" (em forma de abōbada), dm-10 , observou que num setor isolado de $\underline{d m-10}$ havia o efeito de um gene supe pressor, $0 \underline{d m-10-s}$, que restabelecia nesse setor a taxa de crescimento e a morfologia da linhagem selvagem. 0 gene $\underline{d m-10-s}$ é específico para $\underline{d m-10}$ e $\underline{d m-9}$ e não afeta os genes $\underline{d m-2}, \underline{d m-5}$ e $\underline{d m-7}$ da mesma sērie. 0 gene dem-10-s é um supressor intergênico, localizado em algum ponto-do genoma. Sua ação se traduz em produzir um indutor capaz de restringir o repressor produzido pelos genes $\underline{\mathrm{dm}-9}$ e $\underline{\mathrm{dm}-10}$ que restaura 0 fenōtipo selvagem.

ROTHWELL e GREEN (1973) trabalhando com Escherichia coli W.U. - 36-10, obtiveram vārios supressores "amber" (UAG) e "ochre" (UAA) que exibiam novas caracteristicas fenotîpicas através do fenōmeno de interconversão de uma forma em outra. Notaram que linhagens que requeriam tirosina eram suprimidas por supressores "ochre" e as linhagens que requeriam leucina por supressores "amber".

SHARIARI e CASSELTON (1973) determinaram que em Coprinus a mutação no gene met 1 pode ser suprimida por cinco 
genes supressores recessivos diferentes. Os genes su-1. e su-2 apresentam o fenómeno da complementação quando reunidos num he terocārio heterozigoto. Os genes su-3, su-4 e su-5 não se complementam entre si em nenhuma combinação embora se complementem com su-1 e su-2. Apresentam esses genes, diferentes me canismos de supressão. Os genes su-1 e su-2 são alelos não específicos e su-3, su-4 e su-5 são alelos específicos.

CASSELTON e SHARIARI (1974) num trabalho com plementar comentam os vārios aspectos genéticos da recessividade e não complementação de genes supressores "missense" em fungos. Os supressores "missense", isto $\bar{e}$, os que modificam - fenōtipo de mutantes devido a alteração de apenas um aminoàcido na cadeira protéica, podem ser tipos combinados de supressores intergēnicos, intragēnicos e de informação, envol vendo tRNA capazes de modificar as especificidades dos codons.

CASSELTON e SEALY-LEWIS (1976) obtiveram e identificaram em Coprinus quatro genes supressores do locus acu-1, que é um gene estrutural para sintese de acetil-CoA. 0 alelo acu-1-34 foi suprimido pelos quatro supressores os quais são alelo específicos, recessivos e não se complementaram nem em diploides, duplos heterozigotos ou em dicários.

Posteriormente, SEALY-LEWIS e CASSELTON (1976), no mesmo fungo Coprinus isolaram cinco supressores da mutação met-5-1, relativa ao metabolismo da metionina. Todos os supressores são alelo específicos. Dois são recessivos e com - 
plementaram-se normalmente em heterozigotos. Dos outros trēs, dois são recessivos e não se complementaram e o terceiro apre sentou-se dominante.

KOHOUT e BERTRAND (1976) estudaram em Neurospo ra o fenómeno da supressão de mutantes "poky". Tais mutan tes se caracterizam por serem citoplasmáticos, baixo cresci mento, deficiēncia em citocromos mitocondriais aa 3 e $\underline{b}$, excesso de citocromo $\underline{c}$ e sistema respiratório cianido-sensível. Isolaram seis genes nucleares supressores designados sup-l. , sup-3, sup-4, sup-5, sup-10 e sup-14 que não eram alelos e suprimiam o crescimento vagaroso e restabelecendo parcialmente a atividade respiratória. Sugerem os autores que os supressores afetem a estrutura e propriedades de proteinas mito condrio-ribossomais.

BERTRAND e KOHOUT (1977) mostraram que o con teūdo de citocromos mitocondriais aa 3 e $\underline{b}$ em linhagens "poky" é significantemente maior naquelas que apresentam qualquer um dos supressores do que no que não são supressoras.

MC CREADY e COX (1976) estudaram a especificidade de ação de supressores e antissupressores de levedura. Isolaram em Saccharomyces 18 mutantes em oito loci, tidos co mo antissupressores do gene SUP Q-2, um alelo suprimido por mutação "ochre" (UAA) de SUP 11 e cruzaram com trés outros su pressores. Observaram que o gene SUP 2. (que insere tirosina) não foi capaz de suprimir as mutações "ochre" adc 2.l e 
can 1.100 porém suprimia his 5.2 e lys-1.1. Observaram tam bém que nenhum antissupressor afetou a capacidade dodo gene SUP 11-am, um supressor "amber" (UAA) do alelo SUP 11 em suprimir o efeito de trpl. l. , obtido de mutação "amber".

\section{3 - Supressores Diretos (Intragēnicos)}

A partir da década de 1960 intensificaram-se os trabalhos na ārea de supressão direta e de informação como se pode apreciar nos trabalhos de BRENNER e BECKWITH (1965); BRODY e YANOFSKY (1963) ; GORINI e BECKWITH (1966); CARBON , BERG e YANOFSKY (1966) ; GUPTA e KHORANA (1966) ; BERG, YANOE SKY e CARBON (1967) ; CARBON e CURRY (1968); SADGOPAL (1968); HItL e colaboradores (1969) ; WITKIN (1969) ; GORINI (1970) ; YOUNG e COX (1971) ; BAYLISS e VINOPAL (1971) ; BISWAS e GORI NI (1972) ; GORINI (1973); HARTMAN e ROTH (1973) ; ROTHWELL e GREEN (1973) ; GORINI (1974) ; HAWTHORNE e LEUPOLD (1974); EL SEVIERS e GORINI (1975) ; GARVIN e GORINI (1975) entre outros autores.

CRICK e colaboradores (1961) usando supressores intragēnicos vieram a esclarecer algumas propriedades do códi go genētico. Em experimentos com o bacteriófago $T_{4}$, rever tentes espontāneos foram isolados dos mutantes induzidos por proflavina no gene $\underline{\text { rIIB }}$. A reversão não levava exatamente à sequéncia original de nucleótideos do DNA do tipo selvagem. Por teste de recombinação com o selvagem ficou provádo que es 
ses revertentes apresentavam uma segunda mutação na mesma pequena seção (cerca de 1/5) do cistron B que continha a muta ção original. Individualmente cada uma das duas mutações pro duz um fenōtipo mutante, mas juntas produzem um fenōtipo selvagem.

MILLS e ELLINGBOE (1969) descreveram oito reversões induzidas por hidroxilamina num mutante arginina (arg-2) de Schizophylzum commune. Todos eles cresceram em meio mínimo porém são recessivos quando combinados em heterocārios com arg-2. 0 gene arg-2 possui efeito dominante em comple mentação, como algumas vezes ocorre em testes com proteínas de mutantes "missense", quando a enzima é multímera. Sete dos oi to supressores não puderam ser separados de arg-2 porém o su-1 foi separāvel. Em cruzamentos de arg-2 su-1 com o tipo selva gem, seis descendentes idēnticos em suas propriedades ao arg 2 foram recuperados com novo fenōtipo entre treze outros de 87 descendentes testados. Estes $\bar{u}$ titimos recombinantes re queriam arginina, como o $\underline{\arg -2}$. porēm eram eficientes em fracas complementações com arg-2. A complementação é frequentemente encontrada em mutações "missense" bem espaçadas em genes que exibem esse fenómeno de complementação. A interpretação mais simples é de que o supressor su-l è uma nova mutação "missense" no gene arg-2. Pode ser tambëm um defeito no gene que codifica uma proteina diferente que se associa ao produto do gene arg-2 para formar um multimero ativo. Os outros sete su pressores são alterações no codon mutante do arg-2 ou estão 
estreitamente ligadas a segundas mutações "missense" intragênicas. Heterocārios entre arg-2 su-1 e outras linhagens suprimidas crescem em meio minimo, indicando que o bloqueio dominante de complementação pelo arg-2 é aliviado pelo supres sor intragénico. Os autores ficaram impressionados pela alta porcentagem de recombinação entre su-1 e arg-2, que é uma sị tuação anāloga à observada por MORGAN (1966) em Coprinus. GIRARD e ROSSIGNOL (1974) localizaram quatro ge.

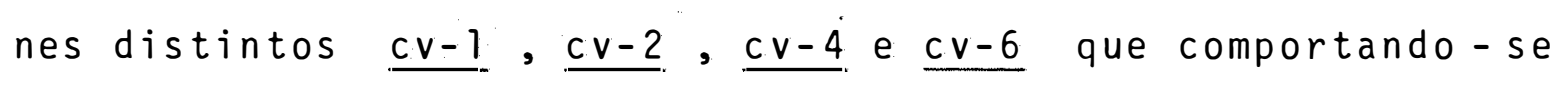
como fatores monogênicos em Ascobolus immersus atuavam como su pressores específicos em genes para pigmentação de esporos

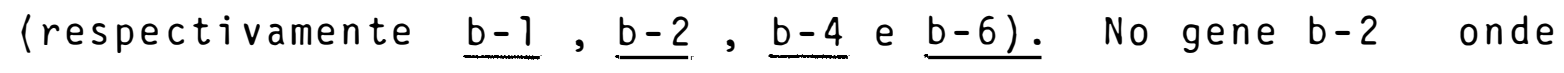
este fenómeno foi estudado em maior detalhe o efeito de cv-2 na supressão da conversão gēnica é quase total. A recombinação intragēnica é muito fortemente diminuida e o "crossing-over" também afetado. Nos genes $\underline{b-1}, \underline{b-2}$ e $\underline{b-4}$ a supressão da conversão só é observada quando o correspondente modificador $\underline{(c v-1}, \underline{c v-2}, \underline{c v-4)}$ estão na condição heterozigōtica. Ob servaram que o gene $\underline{c v-6}$ atua de igual maneira nos genes $\underline{b-6}$, $\underline{c v-1}$ e $\underline{b-1}$ e de maneira diferente no $\underline{c v-2}$ e $\underline{b-2}$, estando todos ligados. Não obtiveram recombinantes entre os modificado res e os genes responsáveis pela pigmentação. A mesma distān cia genética foi observada entre os genes ligados b-4 e b-6 e os genes cv-4 e cv-6. Isto leva a supor que estes modificado res estejam fortemente ligados aos genes correspondentes. 
Observaram também que o $\underline{c v-4}$ tem um certo efeito na recombina ção entre b-4 e $\underline{b-6}$, e também diminui a frequéncia de recombinação quando cv-4 estā em heterozigose.

CULBERTSON e colaboradores (1977) estudaram mu tações "frameshifts" e supressores "frameshifts" em Saccharomyces cerevisae. Mutações "frameshift" são aquelas devidas a ganhos ou perdas de bases em uma dada sequéncia de DNA, causando erro de leitura a partir do ponto de alteração de modo a alterar a sequēncia de aminoācidos da proteina. Usaram ICR-170 como mutagēnico induziram uma dada quantidade de muta ções em levedura que apresentavam um comportamento semelhante ao de mutações "frameshift" em bactērias. Observaram que são mutações polares cuja polaridade pode ser mostrada por supres sores internos, revertem com acridina porēm não são suprimi das por surpessores "nonsense" conhecidos. Observaram tambēm que o fator psi não mendeliano aumenta a eficiēncia de alguns supressores de mutações "frameshift".

\section{4 - SuPREssores de Informaç̃o}

Os supressores de informação são os que mais tēm atraĩdo a atenção dos pesquisadores que atuam nesta ārea. As revisões de GORINI (1970), CASSELTON (1971) e HARTMAN e ROTH (1973) evidenciam claramente que os microrganismos, tanto procariotos quanto eucariotos, têm sido o mais farto mate- 
rial de trablaho e que mais têm fornecido informações quanto ao fenōmeno da supressão.

TODD e CASSELTON (1972) estudaram uma série de supressores recessivos em Coprinus lagopus quando ao aspecto de complementação e mecanismo de ação desses supressores. 0 servaram que os supressores são específicos para cada elelo $\underline{a}$ nalisado e que também não se complementam. Estas duas proprie dades são prōprias de mutações "missense" pois especificam tRNA com especificidade alterada para os codons modificados. os su+ tRNA de mutações "missense" não competem em expressão com seus correspondentes su+ tRNA, com com os tRNA codifica dos por outros genes que normalmente transcrevem o codon mutante. Comparada com um haplóide, a quantidade relativa de

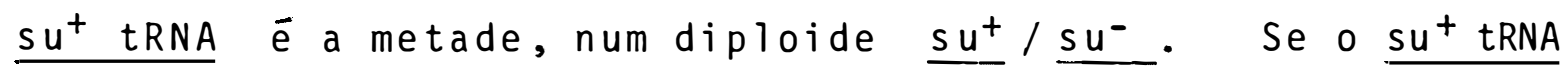
tem baixa eficiēncia, sua atividade no diplóide pode não ser expressada, levando a crer que o gene ${\underline{s u^{+}}}_{\text {_ }}$ pareça recessivo.

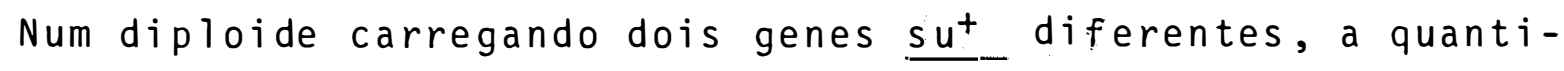

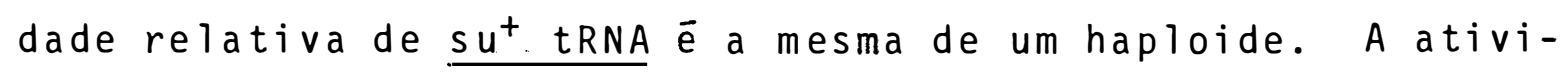
dade do supressor é tão expressa, levando a uma aparente nãocomplementação.

TODD e CASSELTON (1973), usaram mutações no ge ne acu-I, de Coprinus, que conduz à inabilidade para uso de acetato como ūnica fonte de carbono, para selecionar mutações génicas recessivas supressoras. De cinco alelos acu-l. testa dos, dois, acu-I-2 e acu-I-4 eram suprimidos. Trés genes 
supressores diferentes suprimiam a mutação acu-I-2 e dois suprimiam a mutação acu-I-4. Todas as mutações supressoras eram completamente alelo-específicas pois somente suprimiam a muta ção acu-I para a qual foram selecionadas. 0 mecanismo de não complementação e recessividade foi comentado com base na supressão informacional atravēs de erro na tradução causada por moléculas de RNA de transferēncia modificados adquirindo uma nova especificidade de codon.

SHAHRIARI e CASSELTON (1974), num trabalho sub sequente testaram a habilidade de quatro genes supressores da mutação met-1-1 em suprimir met-1-2, uma segunda mutação de met-1. Os supressores que exibiram complementação, sup-l. e sup-2. provaram ser alelos não específicos e suprimiram ambas as mutações met-1. Os supressores que não exibiram complemen tação, sup-3 e sup-5 eram alelo específicos, pois somente su primiram a mutação met-1-1. Em seguida, os autores CASSELTON e SHAHRIARI (1975), testaram a habilidade desses supressores em suprimir dois outros mutantes bloqueados na biossīntese da metionina, met-5 e met-8. Os supressores sup-1 e sup 2 supriram met-8 enquanto sup-3 e sup-5 suprimiram somente a mu tação met-1-1. Nenhum dos supressores suprimiu met-5. Os au tores concluiram que hā dois grupos funcionalmente diferentes de supressores para a marca met em Coprinus. As mutações sup-1. e sup-2. são supressores funcionais que fecham uma via metabölica alternativa corrigindo o efeito das lesões met - 1 . 
e met-8 mas não a lesão met-5, enquanto sup-3 e sup-5 são supressores "missense" informacionais que traduzem especifica mente o codon mutante met-1.

LEWIS e CASSELTON (1975) relataram a identificação de um supressor instável, sup- $6^{+}$em Coprinus Zagopus. 0 supressor podia ser mantido em meio minimo, mas era perdido em meio contendo D-L metionina e L-metionina. Isolamento de extremidades de hifas de linhagens monocarióticas carregando sup- $6^{+}$originou trēs tipos de colōnias: o tipo paternal instável, o auxotrōfico met-l estável e o prototrófico estável que crescia pouco e era inibido por crescimento em meio de me tionina. 0 tipo sup- $6^{+}$estāvel foi isolado de dicārios forma dos entre a linhagem instāvel sup $-6^{+}$e linhagens carregando 0 alelo selvagem do gene supressor. Em cruzamentos sexuais somente o auxotrófico met-1 segregou. 0s autores sugeriram que a linhagem instāvel sup- $6^{+}$possui um cromossomo extra carre gando a mutação sup $-6^{+}$. As pressões seletivas em diferentes meios justificam a perda de cromossomos duplicados. Os resul tados foram interpretados como sendo supressão missense por um tRNA mutante indispensāvel.

ESSER e STAHL (1973) estudando o controle da formação de corpos de frutificação no basidiomiceto Polyporus ciliatus que é controlada por fatores morfogenéticos e de incompabitilidade, verificaram a formação de frutificações anor mais com micēlio verdadeiramente monocariótico obtido a par- 
tir de estoques dicariáticos estāveis. Durante cruzamentos es tudados entre frutificadores monocarióticos um novo fenōmeno foi observado. Em todos os cruzamentos nos quais ocorria migração nuclear, a frutificação monocariótica foi inibida logo que o heterocário foi estabelecido. Os autores concluiram que a ação de genes responsāveis por esta frutificação monocariótica é suprimida logo que nūcleos com diferentes fatores de incompatibilidade estejam em um citoplasma comum.

GORINI (1973) estudando o papel dos ribossomos na fidelidade da tradução da mensagem genética observou que mutações ribossōmicas str A restringiam a eficiēncia de supressores de tRNA (supressores de informação). A mutação Ram, outra mutação ribossōmica reverte todas as restrições.

NEWCOMBE e GRIFFITHS (1973) mostraram em Neurospora a ação de oito super-supressores testados em duas linhagens (76 $\mathrm{AD} 3 \mathrm{~B})$. Observaram que treze mutantes foram suprimidos pelo menos pela ação de um super-supressor, fossem $\underline{e}$ les mutantes "nonsense" ou "missense".

PICARD (1973) obteve 41 supressores de dois mu tantes polares do segmento 29 em Podospora anserina apōs tra tamento com os mutantes $N$-metil-N'-nitro-N-nitrosoguanidina e metano sulfonato de etila.

Os supressores foram diferenciados em trés clas ses (classe I, II e III) pelo critério do espectro padrão. Em cada classe, pelo menos um supressor representativo mostrou 
ser gene não específico. A classe I de supressores foi dominante e somente suprimiu mutantes polares no segmento 29 . Os supressores das classes I I e II I foram parcialmente dominan tes e suprimiram mutantes polares e não polares. As diferenças entre as classes II e III pareceram ser somente quantitativas. A autora estabeleceu duas hipóteses para caracterizar - tipo e ação dos supressores: na primeira hipótese, tRNA po deriam estar envolvidos em todas as trés classes de supressão. A classe I seria "nonsense" específica e a classe II e III "nonsense-missense". Na segunda, tRNA estariam envolvidos so mente na classe I, enquanto ambiguidade ribossomal poderia ser responsāvel pela classe II e III de supressão.

RY CE, TAKINS E HUSSEY (1973) verificaram que mutações UGA em Salmonelza typhimurium podem ser suprimidas por mutações posteriores em outros dois loci, o sup-k locali zado a 95 minutos no mapa e sup-s a 122 minutos. Observaram, tambēm que mutações "frameshift" podem ser suprimidas por mutações em seis loci, de suf A a suf $F$ localizados a 19,45 , 73 , 95 , 116 e 128 minutos de mapa, respectivamente. Estes seis loci afetam os tRNApro e tRNAgly, isto é, os tRNA da prolina e da glicina e parecem permitir leitura de sequências de quatro bases em determinados locais "frameshift".

KOLTIN e DAY (1976), estudando a supressão do fenōtipo "Killer" em Ustizago maydis cruzaram 19 linhagens de células sensitivas com três linhagens "Killer". Cruzamentos 
envolvendo 11 linhagens deram frequēncias de "Killer" ao redor de $71 \%$ a $100 \%$ da progēnie. Em oito linhagens a segregação apresentou frequēncia de "Killer" de $0 \%$ a $58 \%$. Muitos dos "Killer" eram instāveis em determinadas culturas e a supressão mostrou vários graus de especificidade, parecendo ser citoplasmaticamente determinada numa linhagem.

FARMER (1977) mostrou que em Drosophila melano gaster, em muitos estoques de laboratório existe o supressor Su (wco-2) que altera o fenótipo de moscas WCO-2 para fenótipos selvagem. E um supressor específico para o locus, dominante, viāvel em homozigose localizado perto de sy (bwv-l) no braço direito do cromossomo 2 e mostra efeito de dose simples. 0 grau de supressão depende do "background" genētico-- Maiores detalhes de supressores em Drosophiza podem ser encontrados no trabalho de MONTEIRO (1979).

SEALY-LEWIS e CASSELTON (1977) analisando $21 \mathrm{mu}-$ tações gênicas supressoras da mutação met-5-1, que são "missense", no fungo Coprinus, clasificaram-nas em seis grupos

( $A$ a $F$ ) baseados na dominância ou recessividade, ligação ao locus met-5, complementação em cēlulas heterozigóticas e com portamento do crescimento. O número de loci supressores não pode ser determinado pois cruzamentos entre linhagens portado ras de supressores foram inviāveis. Consideram os autores que os genes supressores do locus met-5 causem correções a nível de transcrição. Em quatro grupos ( $C$ a $F$ ) os supressores se 
mostraram com propriedades esperadas para mutações em genes es truturais que codificam tRNA. 0 grupo $C$ se mostrou dominante e as demais mutações foram recessivas e não se complementaram em células heterozigotas. A eficiēncia de supressão foi testada comparando-se a depressão da taxa de crescimento causada fazendo-se as linhagens crescerem em meio suplementado com me tionina. As mutações dominantes foram os supressores mais eficientes, pois foram as que mais influenciavam negativamente a taxa de crescimento. Observaram também que mutações no gru po $A$ e B diminuiam mais o crescimento que mutações no tRNA po rém afetavam algum outro componente na transcrição, pois eram recessivas e se complementavam normalmente. Sugerem que sejam alterações nos tRNA que modificam enzimas.

\section{5 - Principais Aspectos da Supressão Gênica em aspergizlus nidulans ENVOLVENDO O GENE NIC B 8}

No fungo Aspergizzus niduzans o fenōmeno da supressão gēnica é relativamente pouco estudado. Os trabalhos pioneiros, que de modo geral se relacionaram ao isolamento e caracterização de supressores e seus mecanismos de supressão encontram-se referidos nos trabalhos de MIRANDA FILHO (1972), MONTEIRO (1979) e BAL e colaboradores (1979).

WARR e ROPER (1965) iniciaram os estudos de su pressão envolvendo a marca nic B 8 . Estudaram linhagens mu- 
tantes de Aspergizzus niduzans que conferiram resistēncia à diversas substāncias. Observaram que o mutante pf 21. (resistente a $p$-fluoro-fenilalanina) tambēm conferia resistēncia a iodo-acetato e agia como supressor de nic B.8 , que era o mutante deficiente em àcido nicotínico.

MIRANDA FILHO (1972) e MIRANDA FILHO e AZEVEDO (1974) estudando a supressão da marca nic B 8 . em Aspergizlus niduzans isolaram 11 supressores desta marca tendo mapeado no ve destes no grupo de ligação VII. Atravēs da anālise meiótị ca os supressores foram mapeados em relação as marcas nic B 8 e $\underline{v-10}$ verificando-se que três supressores (su 2 , su 4 e su 9) são proximais em relação às marcas e outros quatro (su 1 , $\underline{\text { su } 3}$, su 5 e su 8) são distais. $0 \underline{\text { su } 7}$ (que envolve duplica ção tem posição indeterminada e su 6 é um supressor intragêni co. Os testes de alelismo revelaram serem os supressores ale los entre si e que, portanto, existem quatro loci supressores. Todos os supressores, exceto su 7, tem efeito pleiotrópico, pois além de suprimirem a deficiencia para ácido nicotínico conferem resistência a p-fluorofenilalanina. Para explicar o modo de ação dos supressores os autores propuseram um mecani $\underline{s}$ mo de regulação em cascata.

MONTEIRO (1979) obteve sete novos supressores do mutante nic B 8 de Aspergizlus nidulans, espontaneamente e por ação de luz ultravioleta. Os sete supressores foram a- 
nalisados geneticamente e mapeados em diferentes grupos de li gação: trēs genes foram localizados no grupo de ligação IV, um no grupo de ligação VI e dois genes no grupo de ligação VII. Somente uma mutação caracterizou-se como reversão verda deira de nic B 8 .

0 modo de ação dos supressores, relacionados com o mecanismo da regulação da sintese de ácido nicotínico, foi ex plicado com base no sistema de regulação em cascata proposto por PONTECORVO (1963). Entretanto, postulou-se também um sís tema alternativo deste, no qual o produto gēnico do supressor atua como co-repressor que juntamente com o repressor produzi do pelo locus $R_{1}$ da sintese de ácido nicotinnico formam um com plexo repressor que bloqueia a ação de genes estruturais. Vā rios supressores nic B 8 - evidenciaram capacidade de interfefir no mecanismo de sintese do tiossulfato de sōdio, quer seja de maneira positiva, quer seja de maneira negativa. 


\section{3 - MATERIAL E MÉTODOS}

\section{1 - LINHAGENS}

As linhagens utilizadas neste trabalho são derivadas da linhagem selvagem de Aspergizlus nidulans isoladas por YUILL (1939). São originadas dos estoques do Departamento de Genética da Universidade de Glasgow, Escócia, e manti das pelo Departamento de Genética da Universidade de Sheffield, Inglaterra. As linhagens MSE su nic B 8 e pyro A2 ; nic B 8 foram obtidas no Setor de Microrganismos do Instituto de Genética da Escola Superior de Agricultura "Luiz de Queiroz", da Universidade de São Paulo, Piracicaba, SP. Essas linhagens e suas características genéticas são mostradas na Tabela 1 e os símbolos dos genes mutantes e seus respectivos fenótipos estão na Tabela 2. Na Figura 1 estão representados os grupos de ligação do Aspergizzus niduzans com os marcadores genéticos 
utilizados neste trabalho, de acordo com CLUTTERBUCK (1974), com os simbolos propostos por CLUTTERBUCK (1973).

\section{2 - Meios de Cultura}

\subsection{1 - MEIO MİNIMO}

Preparado de acordo com PONTECORVO e col.(1953) modificado por AZEVEDO e COSTA (1973).

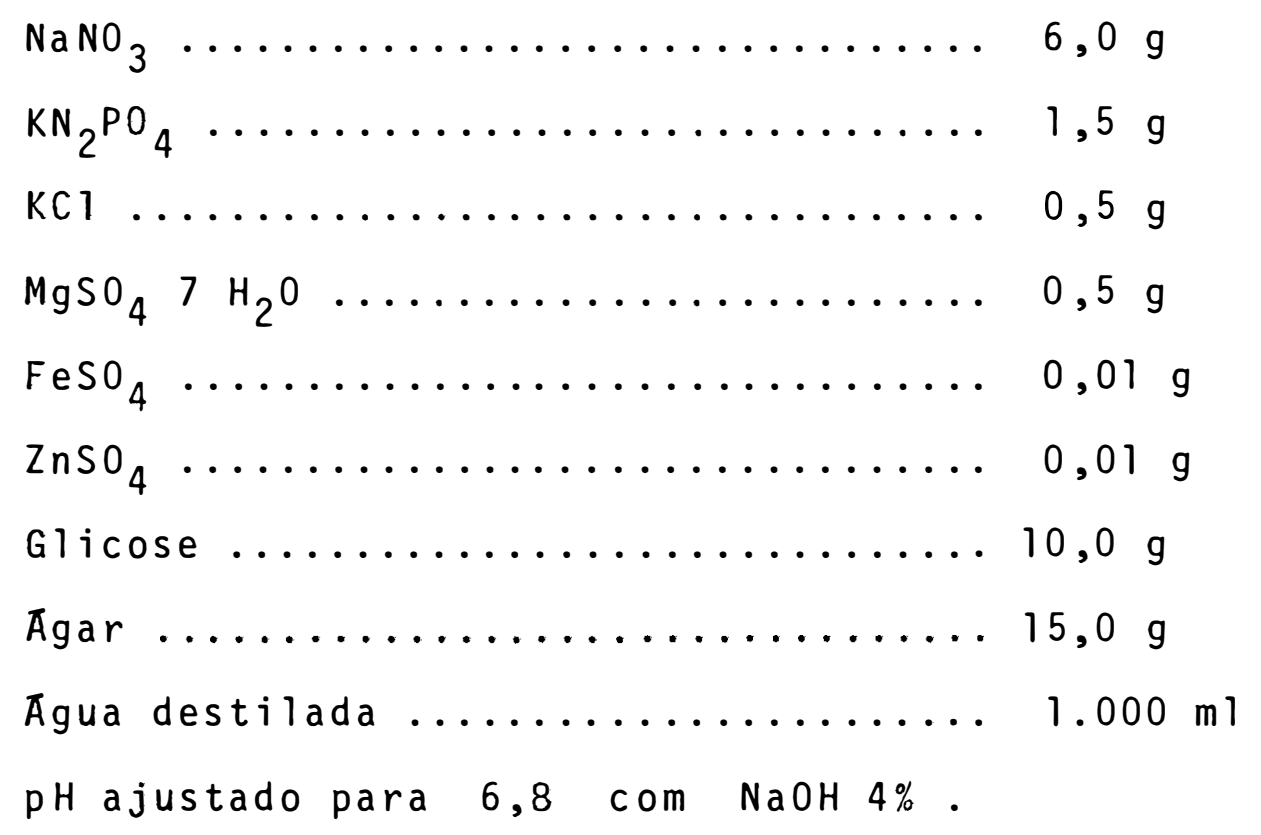

\section{2 .2 - MEIO COMPLETO}

Preparado também de acordo com PONTECORVO e col. (1953), modificado por AZEVEDO e COSTA (1973), adicionando-se ao meio minnimo: 
TABELA 1 - Lista das linhagens de Aspergizzus nidulans utilizadas neste trabalho com seus respectivos marcadores genēticos e origem

\begin{tabular}{|c|c|c|}
\hline Linhagem & Genōtipo & Referéncia \\
\hline $\begin{array}{l}\text { "Master Strain " E } \\
\quad \text { (MSE) }\end{array}$ & 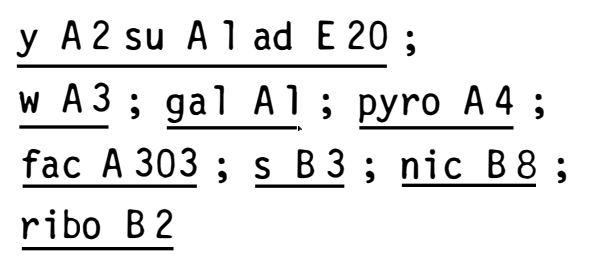 & $\begin{array}{l}\text { Mc CULLY e } \\
\text { FORBES } \\
(1965)\end{array}$ \\
\hline MSE su nic B 8 & $\begin{array}{l}\text { y A2 su A 1 ad E 20; } \\
\text { wA3; gal A 1 ; pyro A 4 ; } \\
\text { fac A 303 ; s B 3 ; } \\
\text { su nic B 8 ribo B 2 }\end{array}$ & $\begin{array}{l}\text { MIRANDA } \\
\text { FILHO } \\
(1972)\end{array}$ \\
\hline 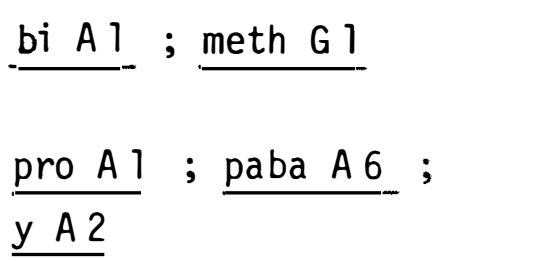 & $\begin{array}{l}\text { bi A I ; meth G1 } \\
\underline{\text { pro A 1 }} \text {; paba A 6 ; y A2 }\end{array}$ & \\
\hline pyro A 4; nic B 8 & pyro $A 4$; nic $B 8$ & $\begin{array}{l}\text { BORDIGNON- } \\
\text { OLIVEIRA } \\
\text { (1978) }\end{array}$ \\
\hline yA2 ; nic $A 2$; ribo D 5 & y A2 ; nic A 2; ribo D 5 & \\
\hline
\end{tabular}


TABELA 2 - Lista dos loci gēnicos das linhagens de Aspergizlus niduzans utilizadas neste trabalho com seus respectivos símbolos, fenótipos e grupos de ligaçāo

\begin{tabular}{|c|c|c|}
\hline Simbolo & Fenōtipo & Grupo de ligação \\
\hline Nutricionais: & $\because$ & \\
\hline ad E 20 & requer adenina & I \\
\hline bi Al & requer biotina & I \\
\hline Fac A 303 & $\begin{array}{l}\text { incapacidade para utilizar } \\
\text { acetato }\end{array}$ & V \\
\hline gal A 1 & $\begin{array}{l}\text { incapacidade para utilizar } \\
\text { galactose }\end{array}$ & I I I \\
\hline meth GI & requer metionia & IV \\
\hline nic $A 2$ & requer àcido nicotīnico & v \\
\hline nic B 8 . & requer ācido nicotínico & VII \\
\hline paba A 6 & requer àcido p-aminobenzóico & I \\
\hline pro A 1 & requer prolina & I \\
\hline$\overline{\text { pyro } A 4}$ & requer pirodoxina & IV \\
\hline ribo B2 & requer riboflavina & VIII \\
\hline ribo 05 & requer riboflavina & v \\
\hline SB 3 & requer tiossulfato de sōdio & VI \\
\hline \multicolumn{3}{|l|}{ Visiveis: } \\
\hline \multirow[t]{2}{*}{ WA 3} & conídios brancos epistāticos & \\
\hline & ou $y$ e $y^{+}$ & II \\
\hline y A2 & conidios amarelos & I \\
\hline \multicolumn{3}{|l|}{ Supressores: } \\
\hline su $A 1$ ad E 20. & supressor de ad E20. & I \\
\hline su nic B 8 & supressor de $\overline{\text { nic B } 8}$. & VII \\
\hline
\end{tabular}




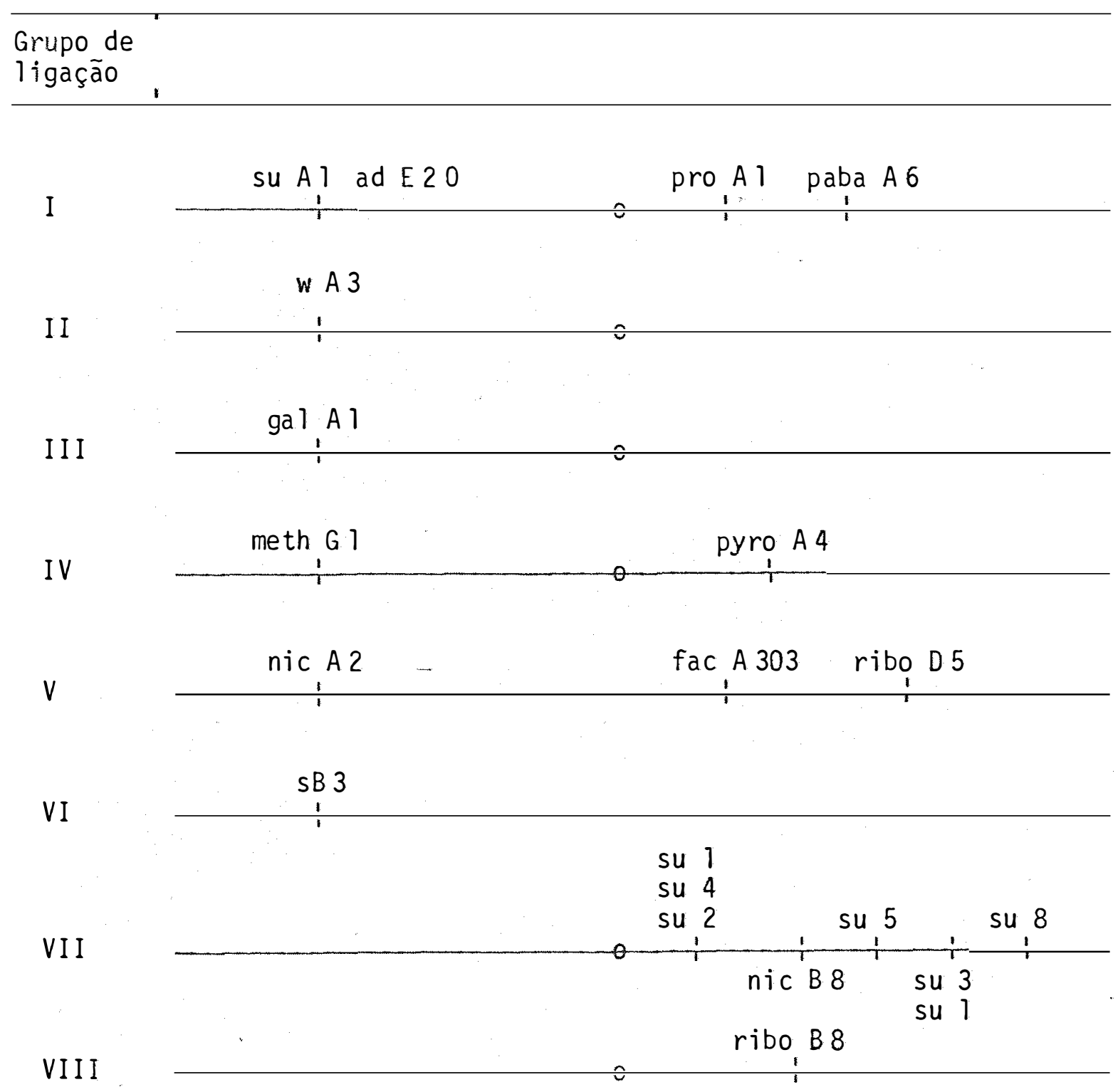

FIGURA 1 - Mapa parcial de ligação de Aspergizlus niduzans, com os marcadores genéticos utilizados neste tra balho. Os centrōmetros estão representados por "o". As posições dos marcadores genēticos não estão em escala no mapa. 


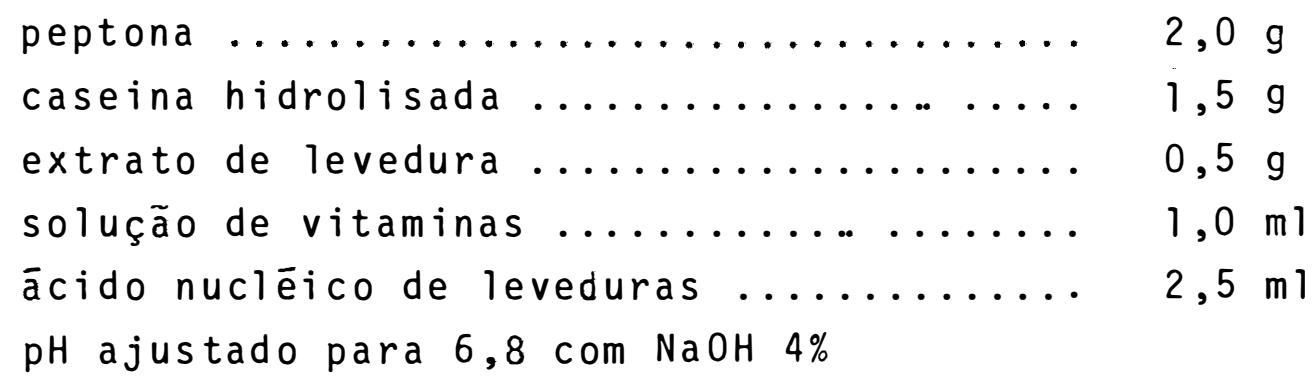

\subsection{3 - Meio de galactose}

Preparado da mesma forma que o meio minimo (ítem 3.2.1) apenas substituindo-se a glicose por galactose como fonte de carbono.

\subsection{4 - Meio de acetato de amōnio (APIRION, 1962)}

acetato de amōnio ............... 12,0 g

fosfato di-hidrogenado de potássio

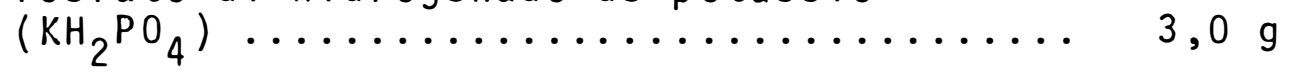

cloreto de sódio $(\mathrm{NaCl}) \ldots \ldots \ldots \ldots \ldots \ldots 2,0 \mathrm{~g}$

sulfato de magnésio hepta-hidratado

$\left(\mathrm{MgSO}_{4} 7 \mathrm{H}_{2} \mathrm{O}\right) \ldots \ldots \ldots \ldots \ldots \ldots \ldots \ldots \ldots \ldots \ldots \ldots \ldots, 0,5 \mathrm{~g}$

sulfato de ferro $\left(\mathrm{FeSO}_{4}\right) \ldots \ldots \ldots \ldots \ldots \ldots, 0,01 \mathrm{~g}$

sulfato de zinco $\left(\mathrm{ZnSO}_{4}\right) \ldots \ldots \ldots \ldots \ldots \ldots, 0,01 \mathrm{~g}$

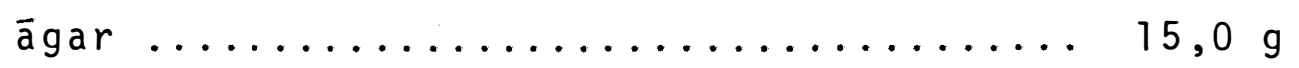

ägua destilada .................. $1.000 \mathrm{ml}$

$0 \mathrm{pH}$ foi ajustado para $6,1 \mathrm{com} \mathrm{NaOH} 4 \%$ 


\section{2 .5 - Meio mínimo líquido mais 2\% de meio completo}

Adicionou-se ao meio mínimo líquido $2 \%$ de meio completo e distribuiu-se em tubos $(2,5 \mathrm{ml}$ por tubo $)$.

\section{3 - SoLuģ̃̃ES}

$$
\begin{aligned}
& \text { 3.3.1 - Solugão de vitami nas }
\end{aligned}
$$

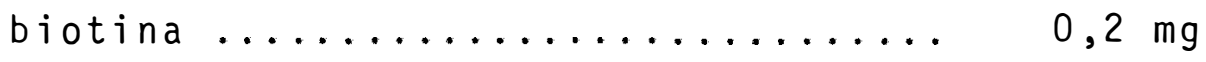

$$
\begin{aligned}
& \text { àcido p-aminobenzōico ........... } 10,0 \mathrm{mg} \\
& \text { aneurina (tiamina) ............. 50,0 } \mathrm{mg} \\
& \text { piridoxina ................... 50,0 mg } \\
& \text { ácido nicotinico ............... 100,0 mg } \\
& \text { riboflovina ................. 100,0 mg } \\
& \text { āgua destilada esterilizada ........ 100,0 m }
\end{aligned}
$$

A solução foi parcialmente esterilizada em ba-

nho-maria por 15 minutos e guardada no refrigerador a $4^{\circ} \mathrm{C}$ em frasco escuro sob clorofórmio.

\section{3 .2 - SOLUção dE ÁCIDO NUCLËICO DE LEVEDURAS}

$\begin{array}{ll}\begin{array}{l}\text { àcido nucleico de } \\ \text { leveduras }\end{array} & \begin{array}{l}2 \mathrm{~g} \text { em } 15 \mathrm{ml} \text { de solução } \\ \text { In de } \mathrm{HCl}\end{array} \\ \begin{array}{l}\text { ácido nucléico de } \\ \text { leveduras }\end{array} & 2 \mathrm{~g} \text { em } 15 \mathrm{ml} \text { de solução } \\ & \text { IN de NaOH }\end{array}$


Ambas soluçõesforam aquecidas a $100^{\circ} \mathrm{C}$ por 20 minutos, misturadas e o pH foi ajustado para 6,0 com NaOH $4 \%$. Filtrou-se e completou-se o volume para $40 \mathrm{ml}$ sendo a seguir conservada no refrigerador a $4^{\circ} \mathrm{C}$, sob clorofórmio.

\section{3 .3 - SOLUGÃO DE TWEEN}

Adicionou-se tween 80 a āgua destilada em uma concentração de $0,1 \%$ ( $v / v)$. A seguir, distribuiu-se em tubos $(2,5 \mathrm{ml}$ por tubo).

\section{3 .4 - Soluģ̃̃o SALINA}

Preparou-se uma solução de cloreto de sōdio a 0,89\% dissolvendo-se o sal em āgua destilada. A solução foi co locada em frascos ( $9 \mathrm{ml}$ por frasco).

\subsection{5 - SUPLEMENTOS ADICIONADOS AO MEIO MÍNIMO}

Preparou-se o estoque de suplementos adicionan do-se cada um deles em āgua destilada esterilizada. A solução foi a seguir colocada em banho-maria por 15 minutos para esterilização parcial e conservada no refrigerador a $4^{\circ} \mathrm{C}$. 
TABELA 3 - Substāncias adicionadas aos meios de cultura

\begin{tabular}{lr}
\hline Substāncia & $\begin{array}{r}\text { Concentração final no } \\
\text { meio de cultura }\end{array}$ \\
\hline Adenina & $25,00 \mu \mathrm{g} / \mathrm{ml}$ \\
Acido nicotínico & $0,50 \mu \mathrm{g} / \mathrm{ml}$ \\
Acido p-amino benzóico & $0,25 \mu \mathrm{g} / \mathrm{ml}$ \\
Biotina & $0,20 \mu \mathrm{g} / \mathrm{ml}$ \\
Metionia & $50,00 \mu \mathrm{g} / \mathrm{ml}$ \\
Piridoxina & $0,25 \mu \mathrm{g} / \mathrm{ml}$ \\
Prolina & $50,00 \mu \mathrm{g} / \mathrm{ml}$ \\
Riboflavina & $0,50 \mu \mathrm{g} / \mathrm{ml}$ \\
Tiossulfato de sódio & $100,00 \mu \mathrm{g} / \mathrm{ml}$ \\
\hline
\end{tabular}

\section{3 .6 - Placas de anÁlise}

Para anālise genētica, utilizaram-se placas de Petri com meio completo, meio minimo, com meio minimo suplementado com todos os requisitos nutrimentais envolvidos no cruzamento e com meio minimo suplementado com todos os requi sitos, exceto os que estavam sob anālise.

\section{4 - Esterilizagão e Incubaç̃o}

Os meios de cultura e as soluções foram sempre esterilizados em autoclave por 15 minutos a uma atmosfera de pressão e a $120^{\circ} \mathrm{C}$. 
A temperatura de incubação foi de $37^{\circ} \mathrm{C}$ em to dos experimentos.

\section{5 - Técnicas de Análise genética}

\subsection{1 - OBTENĢÃo de Heterocários}

Utilizou-se o mesmo método descrito por PONTECORVO e col. (1953) onde conīdios de duas linhagens foram adi cionados em $2,5 \mathrm{ml}$ de meio mīnimo líquido mais $2 \%$ de meio com pleto, o que permite apenas pequena germinação de conídios. Depois de 3 a 4 dias de incubação, formou-se uma película na superficie do meio a qual foi transferida para placas contendo meio mīnimo sōlido.

\section{5 .2 - ANÁLISE MEIŌTICA}

A anālise meiótica baseia-se no ciclo sexual do fungo, atravēs da anālise de ascosporos produzidos em cleis totēcios hỉbridos, segundo o método descrito por PONTECORVO e col. (1953).

0 heterocārio obtido conforme o ítem 3.6 .1 foi transferido para placas contendo meio minimo. As placas foram vedadas com fita celulósica, para favorecer a formação de cleistotécios, e incubados por dez dias. Sob lupa, com auxílio de um fio de platina, os cleistotécios maduros, de maior 
tamanho foram retirados e rolados em placas com meio minimo, a fim de libertā-los das células de "hulle" e conídios aderen tes (BARACHO, VENCOVSKY e AZEVEDO, 1970). Cada cleistotécio limpo foi transferido para tubo de ensaio contendo solução de tween e rompidos na parede do tubo, libertando dessa forma os ascosporos. Com a mesma pipeta utilizada para o esmagamento, a parede do tubo foi lavada suspendendo dessa forma os escosporos na solução de tween. Em placas com meio completo, semeou-se $0,1 \mathrm{ml}$ de cada solução, sendo o restante conservado em refrigerador. Após trēs dias de incubação foi possível verificar se os cleistotécios eram híbridos. Dentre os híbridos, escolheu-se um para anălise dos ascosporos.

os ascosporos do cleistotécio selecionado foram semeados em placas contendo meio completo e âpós três dias de incubação as colōnias foram transferidas para placas de anālise com auxîlio de um replicador de 26 agulhas de niquelcromo, obedecendo a disposição $(5 \times 5)+1$ das colónias nas placas mestras. As leituras foram feitas apōs 24,48 e 72 horas (AZEVEDO e col., 1976).

\section{5 .3 - ANĀLISE MITŌTICA}

Esta foi realizada através do ciclo parassexual, segundo o método de ROPER (1952). Nos setores heterocarióticos, obtidos de acordo com o método descrito no item 3.6.1, a maioria dos conĩdios formados são haploides e não conseguem se 
desenvolver em meio mīnimo, porēm pode haver fusão de nūcleos haplōides formando nūcleos diplóides e não conseguem se desen volver em meio mīnimo, porém pode haver fusão de nūcleos haplóides formando nūcleos diplóides heterozigotos que originam conídios diplóides que são capazes de se desenvolverem em meio minimo. Pelo fato da porcentagem de aparecimento de conídios diplóides ser muito baixa, transferiu-se grande quantidade de conĩdios dos setores heterocarióticos para solução de tween (aproximadamente $10^{7}$ conídios por ml) e semeou-se em placas contendo meio mínimo. Apōs 72 horas de incubação isolaram-se diplóides heterozigotos. Como critério para identificação dos diplóides, baseou-se na capacidade de crescimento em meio minimo e diāmetro dos conídios. A medição do diāmetro dos con í dios foi realizada em microscōpio com ocular micrométrica, tó mando-se cadeias de cinco conỉdios em lámina com lisol diluido $(1: 10)$.

Os diplóides obtidos foram induzidos à haploidização com uso de cloroneb (AZEVEDO e SANTANA, 1975) que ini be o crescimento de diplóides, permitindo o crescimento de se tores haplóides. A haploidização ocorre através de aneuploidia com perdas sucessivas de cromossomos (KÄFER, 1961). A técnica consiste em adicionar $2,5 \mathrm{ml}$ da solução a $2 \%$ de cloro neb em $200 \mathrm{ml}$ de meio completo. Os diplóides foram inoculados nessas placas atravēs de estrias (a fim de se obter maior nūmero de setores haploides) e apōs 7 a 10 dias de incubação 
surgiram setores amarelos e brancos. Apōs se proceder o isolamento e purificação dos setores haploides em meio completo, estes foram inoculados um a um em 26 pontos fixos em placa com meio completo. Apōs trēs dias de incubação, essa placa serviu de placa mestra que foi replicada para placas de anāi se atravēs de um replicador de nĩquel-cromo. Com 24,48 e 72 horas de incubação efetuaram-se leituras das placas de aná lise, anotando-se as colónias que cresceram e as que não cresceram (AZEVEDO, 1973). 


\section{4 - RESULTADOS}

\section{1 - Cruzamentos Controle}

Em primeiro lugar foram feitos cruzamentos con trole para verificar se os genes supressores obtidos a partir da linhagem MSE por MIRANDA FILHO (1972) ainda se mantinham de forma estāvel nas mesmas. Também cruzamentos adicionais foram feitos com outras linhagens usadas no presente trabalho.

\subsection{1 - Resultados DE CRUZAMENTOS DE LinHAgenS COM SU- PRESSORES E LINHAGEM pro A 1 ; paba A 6 ; yA 2}

Foram cruzadas as linhagens MSE su ni B 8 com a linhagem proA 1 ; paba A 6 ; yA2 , para se observar a segregação nic $^{+}: \underline{n i c^{-}}$ 
Tais cruzamentos tiveram a finalidade de confir mar os valores de ligação entre os genes supressores e o locus nic B 8 , obtidos por MIRANDA FILHO (1972). Os resultados en contram-se na Tabela 4.

\section{1 .2 - ANÁLISE MEIŌTI ICA}

A linhagem proA 1 ; paba A 6 ; y A2 foi cruzada com as linhagens MSE (controle de linhagens portadoras de genes supressores). Os resultados da segregação meiōtica foram obtidos por semeadura de uma amostra de ascosporos provenientes dos cruzamentos acima mencionados. Estes resultados são'mostrados na Tabela 5.

\section{1 .3 - ANĀLISE MITÓTICA}

Setores haploides foram isolados a partir de diplóides obtidos nos heterocārios das linhagens MSE su nic B 8 com a linhagem proA 1 : paba A 6 ; yA2. Analisado mitoti camente, forneceram-se os resultados que constam na Tabela 6. 


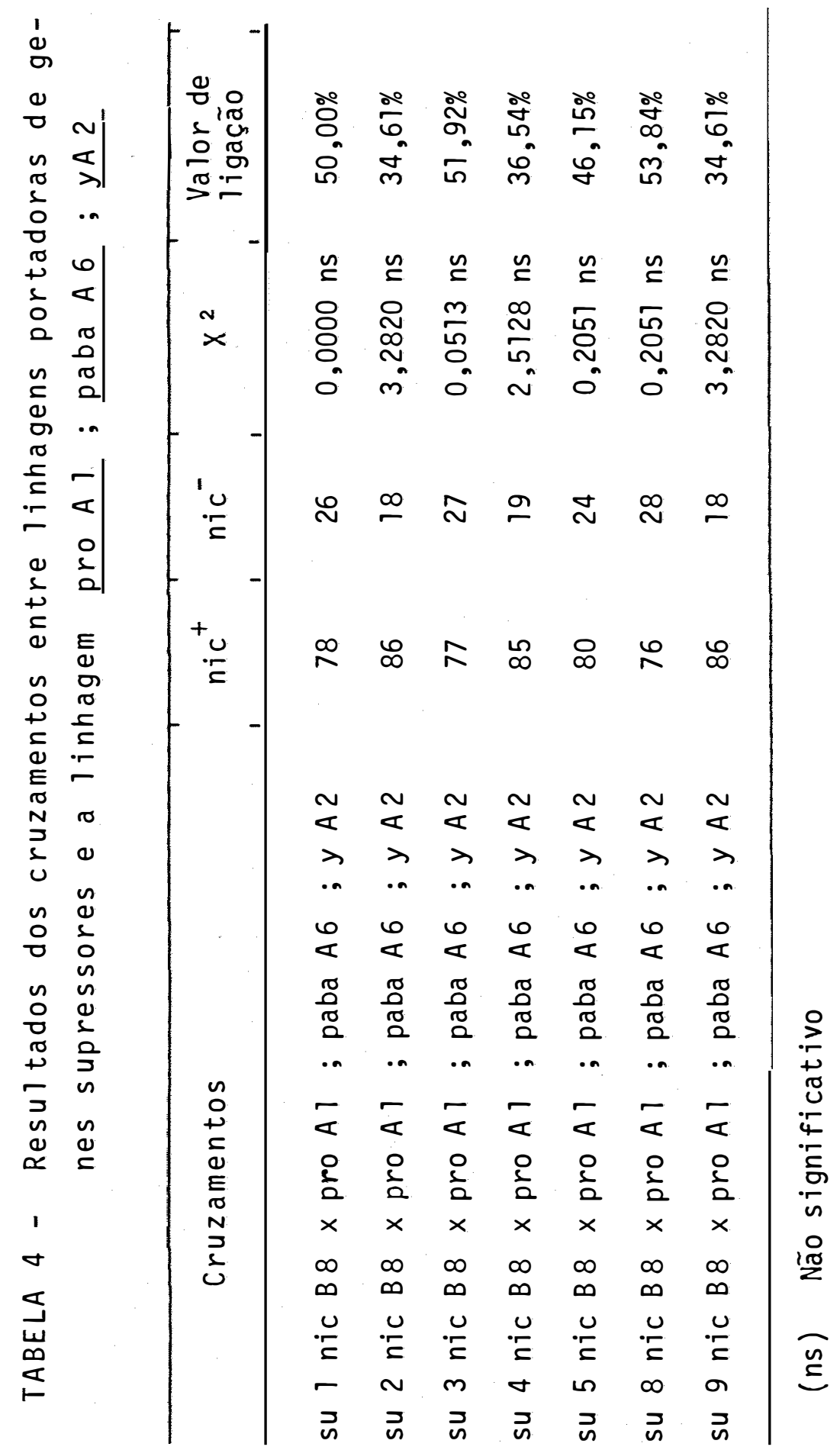


TABELA 5 - Segregação meiótica do cruzamento das 1 inhagens supressoras com a 1 inhagem proAl; paba A6; $\underline{y A 2}$.

\begin{tabular}{|c|c|c|c|c|c|}
\hline \multirow{2}{*}{$\begin{array}{l}\text { Cruzamento pro A 1; } \\
\text { paba } \text { f } 6_{2} ; \text { y } 2 \text { com: }\end{array}$} & \multicolumn{3}{|c|}{ Segregantes } & \multirow{2}{*}{$\begin{array}{l}\text { Propor } \\
\text { ção es } \\
\text { peradă }\end{array}$} & \multirow{2}{*}{$x^{2}$} \\
\hline & Brancos & Amarelos & Tota 1 & & \\
\hline MSE * & 265 & 269 & 539 & $1: 1$ & 0,1503 n.s. \\
\hline su 1 nic $B 8$ & 387 & 375 & 762 & $1: 1$ & 0,1890 n.s. \\
\hline su 2 nic $B 8$ & 352 & 347 & 693 & $1: 1$ & 0,1746 n.s. \\
\hline su 3 nic B8 & 215 & 245 & 460 & $1: 1$ & 1,9566 n.s. \\
\hline su 4 nic B8 & 363 & 349 & 712 & $1: 1$ & 0,2752 n.s. \\
\hline su 5 nic B8 & 236 & 260 & 496 & $1: 1$ & 1,2204 n.s. \\
\hline su 8 nic B8 & 282 & 273 & 555 & $1: 1$ & 0,1458 n.s. \\
\hline su 9 nic B8 & 347 & 317 & 658 & $1: 1$ & 1,9696 n.s. \\
\hline
\end{tabular}

${ }^{*}$ ) cruzamento controle (ns) não significativo 
TABELA 6 - Resultados da anālise mitotótica de setores haplóides obtidos de diplóides MSE su nicB 8 // proA

\begin{tabular}{|c|c|c|c|}
\hline \multirow{2}{*}{$\begin{array}{l}\text { Requerimento } \\
\text { analisado }\end{array}$} & \multicolumn{3}{|c|}{ Supressor de nic 8 analisado } \\
\hline & su 5 & su 8 & su 9 \\
\hline$n i c+$ & 52 & 52 & 52 \\
\hline nic - & 0 & 0 & 0 \\
\hline
\end{tabular}

\subsection{4 - Cruzamento da Linhagem MSE com a Linhagem pro A 1 ; paba A 6 ; yA 2}

Executado a título de controle em relação às linhagens supressoras, este cruzamento exibiu uma segregação meiōtica na proporção de $1: 1$ para todas as marcas genéticas, o que ratifica plenamente a segregação esperada, não se obtendo significância alguma em relação a qualquer uma das mar cas. Fica então perfeitamente caracterizado que em condições normais a segregação não se altera.

Os resultados encontram-se na Tabela 7. 
TABELA 7 - Anālise meiótica do cruzamento da linhagem MSE com a linhagem proA1; paba A 6 ; yA 2

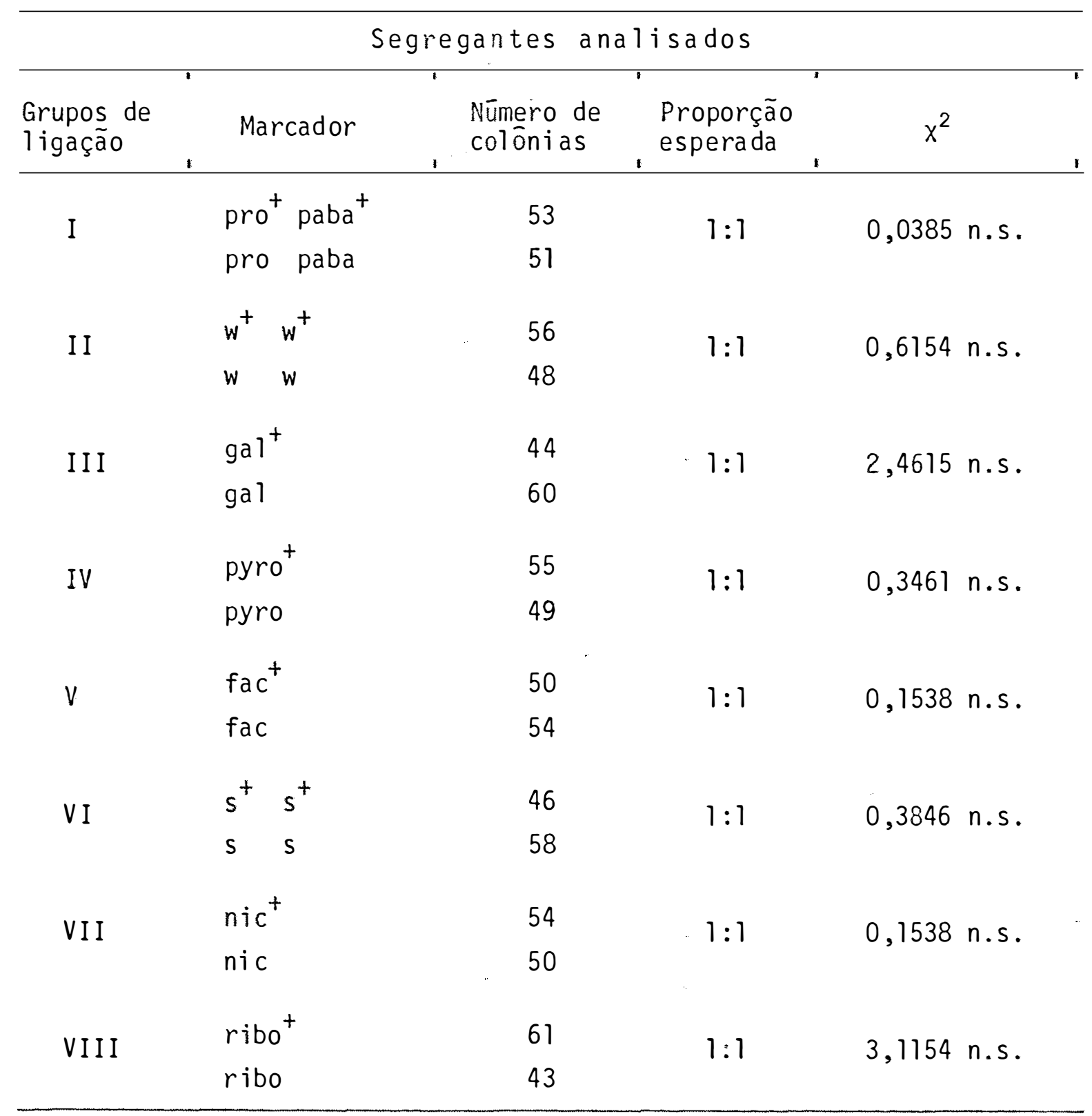




\section{1 .5 - RESULTADOS DE CRUZAMENTOS ENTRE A LINHAGEM Y A 2 ; niC A 2 ; ribo D COM A LINHAGEM bi A 1 ; meth G1}

Foram cruzadas as linhagens bi A I ; meth GI com y A 2 ; nic A 2 ; ribo D 5 e os segregantes foram analisados quanto à capacidade de crescimento em meio de cultura com ácido nicotínico e em ausēncia dele. Os resultados podem ser observados na Tabela 8.

TABELA 8 - Resultados do cruzamento entre as linhagens bi A I ; meth G1 e yA2 ; nic A2 ; ribo D 5

\begin{tabular}{ll}
\hline Cruzamento nic $+n i c-$ & $\begin{array}{l}\text { Proporção } \\
\text { esperada }\end{array}$ \\
\hline
\end{tabular}
y A2 ; nic A2 ; ribo D 5

$\begin{array}{llll}x & 39 & 39 & 1: 1\end{array}$

bi Al ; meth G1

\section{1 .6 - ANÁLISE DE HETEROCÁRIOS E DIPLÓIDES}

Foram realizados heterocārios entre as linha gens com supressores e a linhagem pyro A 4, nic B 8 , aqui designada tecnicamente de linhagem 33 , por ser 033 . segregante de um cruzamento entre linhagens deficientes em ácido p-aminobenzóico e piridoxina, efetuado por BORDIGNON OLIVEIRA (1978). 
Os resultados encontram-se na Tabela 9.

TABELA 9 - Heretocārios e diplóides entre as linhagens com supressores e a linhagem 33

\begin{tabular}{|c|c|c|c|c|c|c|}
\hline & \multirow{2}{*}{\multicolumn{2}{|c|}{ " }} & \multicolumn{2}{|c|}{ Heterocārios } & \multicolumn{2}{|c|}{ Diplōides } \\
\hline & & & $\mathrm{nic}^{+}$ & $\mathrm{nic}^{-}$ & $\mathrm{nic}^{+}$ & $\mathrm{nic}^{-}$ \\
\hline su & $1 / /$ & 33 & + & + & + & + \\
\hline su & 2 // & 33 & + & + & + & + \\
\hline su & $3 / /$ & 33 & + & + & + & + \\
\hline su & $4 / /$ & 33 & + & + & + & + \\
\hline su & $5 / /$ & 33 & + & + & + & + \\
\hline su & $6 / 1$ & 33 & + & + & + & + \\
\hline su & $8 / /$ & 33 & + & + & + & + \\
\hline su & 9 // & 33 & + & + & + & + \\
\hline
\end{tabular}




\section{2 - Testes de Especificidade}

Para se observar a especificidade de ação supressora, as linhagens de Aspergizzus niduzans portadoras de genes supre-sores do locus nic B 8 , para deficiēncia em ácido nicotinico, foram cruzadas com a linhagem y $\underline{\text { y 2 }}$; nic A2 ; ribo D 5 que apresenta o locus nic A2 localizado no grupo de ligação $V$ e não no grupo de ligação VII como o gene nic B8. Os supressores de nic B 8 poderiam suprimir ou não o efeito do mutante nic A 2. No caso de especificidade de ação, isto é, sunic B 8 não ser capaz de suprimir o mutante $\underline{\text { nic A 2 }}$, a proporção de $5 \mathrm{nic}^{-}: 3 \mathrm{nic}^{+}$é suficiente para explicar os resultados.

Esta hipótese foi testada e os dados obtidos en contram-se na Tabela 10. 


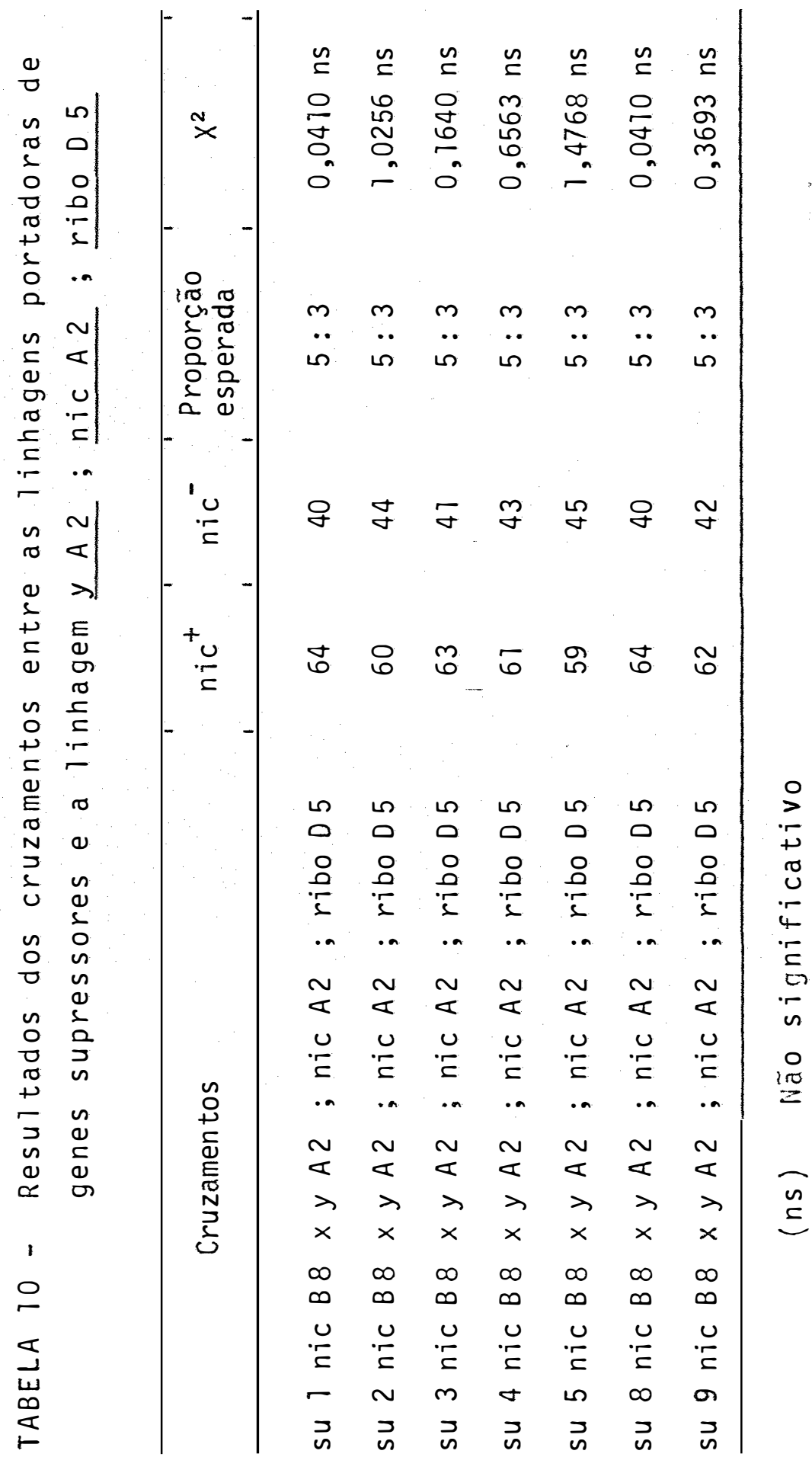


55.

\section{3 - Cruzamentos de Linhagens com Genes Supressores E OUtRAS LinHAgens}

\subsection{1 - CRuzalientos DAS Linhagens COM GENES SUPRES- SORES E A LINHAGEM pyro A 4 ; nic B 8}

Estes cruzamentos foram realizados com a fina-

lidade de se reunir numa mesma linhagem dois genes supressores do mutante nic B 8 .

A I inhagem pyro A 4 ; nic B 8 é a linhagem 33, anteriormente referida no item 4.1.6. Esta linhagem foi cruzada com as portadoras de genes supresores (su l, su 2 , $\underline{\text { su } 4}, \underline{\text { su } 5}, \underline{\text { su } 8}$ e su 9). Do cruzamento entre su $8 \times 33$, foi obtido o segregante $n 0^{--13}$, que apresentava as marcas genēticas su 8 nic B 8 ; pyro A 4 ; paba A6. Na hipōtese de se haver dois supressores na mesma linhagem, foram testadas as proporções esperadas de $6 \mathrm{nic}^{+}: 2 \mathrm{nic}^{-}$para o caso de haver manutenção do efeito de supressão e de $4 \mathrm{nic}^{+}: 4 \mathrm{nic}^{-}$, caso dois supressores na mesma linhagem cancelassem mutuamente $\quad$. efeito de supressão. Os resultados desses cruzamentos encontram-se na Tabela 11 .

Do cruzamento entre su 3 nic B 8 e a linhagem pyro A 4 ; nic B 8 foram obtidos värios segregantes com o fenōtipo nic ${ }^{+}$por supressão. 
56.

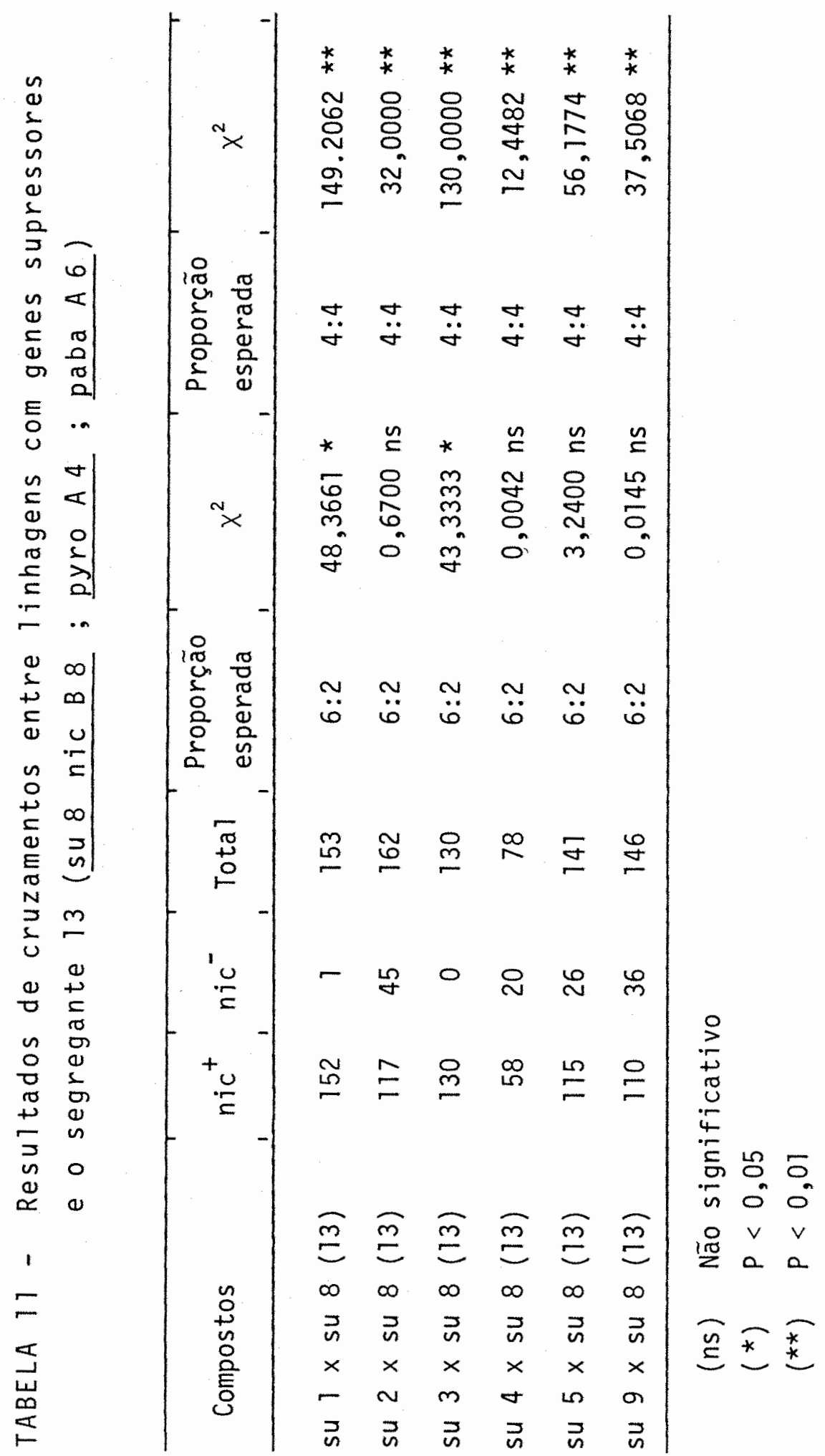


o genótipo dos segregantes escolhidos foram os seguintes: 301 : su 3 nic B 8 ; ribo B 8;s B 3 ; pyro A 4; ad E 20; 304 : su 3 nic B 8; pyro A 4 ; paba A 6; 309: su 3 nic B 8 ; ribo B 8 ; pyro A 4 ; paba A 6 ; 315: su 3 nic B 8 ; ribo B 8; s B 3 ; pyro A 4 e 319: su 3 nic B 8 ; S B 3 ; pyro A 4 ; paba A 6.

A semelhança do que foi feito com o segregante 13 (su 8 nic B 8 ; pyro A 4 ; paba A 6) estas linhagens foram cruzadas com as demais linhagens contendo genes supressores (su 2 , su 4, su 5 , su 8 e su 9). os resultados obtidos encontram-se na Tabela 12.

\section{4 - Anālise dos Segregantes que Possivelmente Cont inham Dois Supressores para a mesma Deficiéncia}

Para se saber se a presença do dois supresso res para a mesma deficiēncia, reunidos numa mesma linhagem mantinham efeito de supressão ou se cancelavam-se mutuamente, foram efetuadas sēries de cruzamentos em que se escolhiam, ao acaso, colōnias que exibiam fenótipo $\underbrace{n i c^{+}}$entre os segregantes dos cruzamentos cujos dados constam da Tabela 12.

As linhagens escolhidas foram cruzadas com a linhagem bi A _ ; meth GI, de coloração verde e fenótipo nic ${ }^{+}$. De tais cruzamentos foram escolhidos segregantes ao acaso e analisados quanto a prototrofia em relação ao ácido nicotínico. 
Tais segregantes (que exibiam o fenōtipio nic ${ }^{+}$) poderiam conter um ou dois genes supressores do mutante nic B 8.

A proporção de $6 \mathrm{nic}^{+}: 2 \mathrm{nic}^{-}$é suficiente pạ ra explicar a presença de um supressor nas linhagens testadas. Para se tentar pesquisar a presença de dois su pressores na mesma linhagem foram testadas as proporções de $7 \mathrm{nic}^{+}: 1 \mathrm{nic}^{-}$e $5 \mathrm{nic}^{+}: 3 \mathrm{nic}^{-}$.

A proporção $7 \mathrm{nic}^{+}: 1 \mathrm{nic}^{-}$é suficiente para explicar a manutenção do efeito de supressão quando dois supressores para a mesma deficiēncia estão reunidos na mesma $1 \underline{i}$ nhagem e $5 \mathrm{nic}^{+}: 3 \mathrm{nic}^{-}$quando esses dois supressores cance lam-se mutuamente.

Os resultados obtidos encontram-se nas Tabelas

13 a 15. 


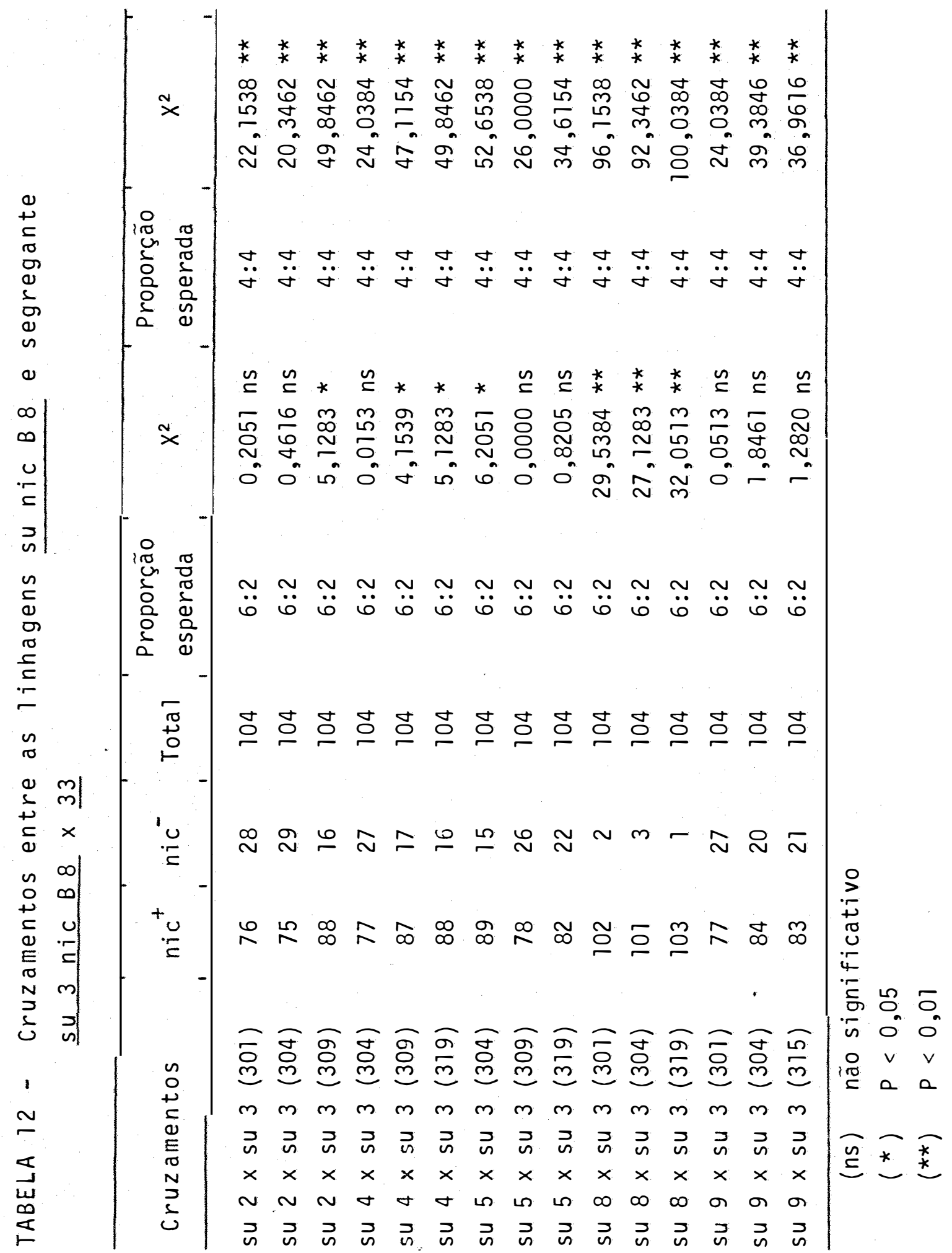




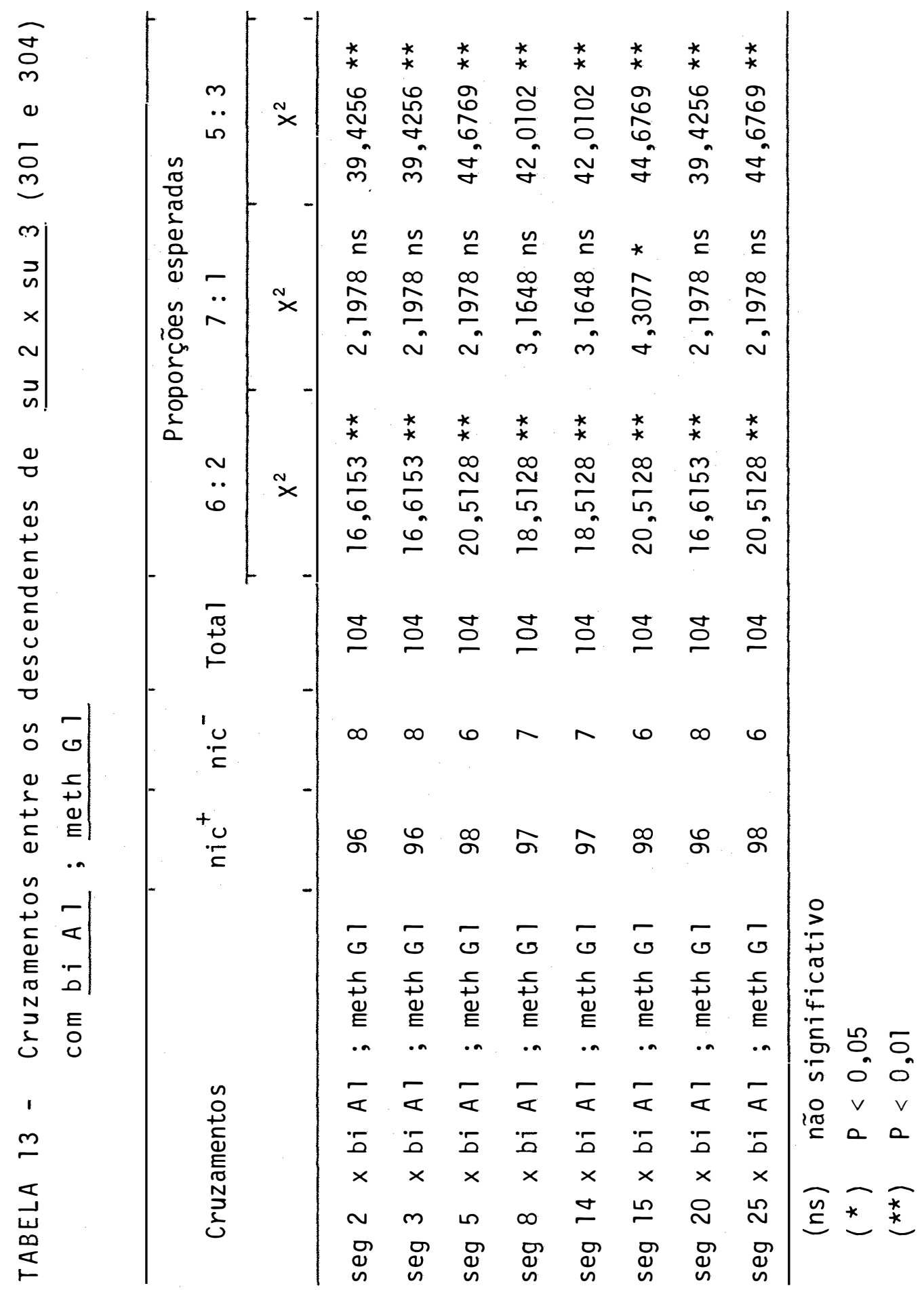




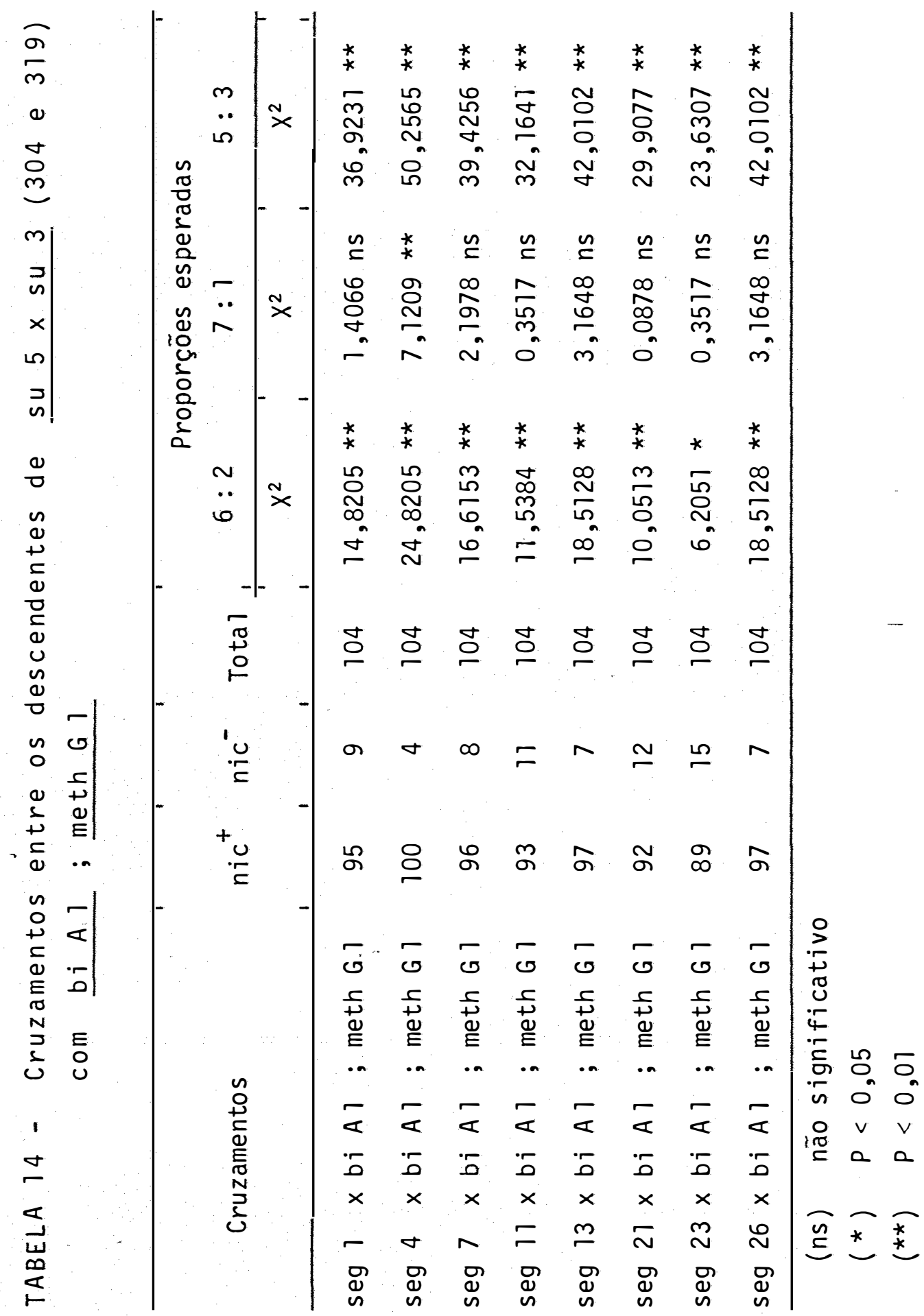




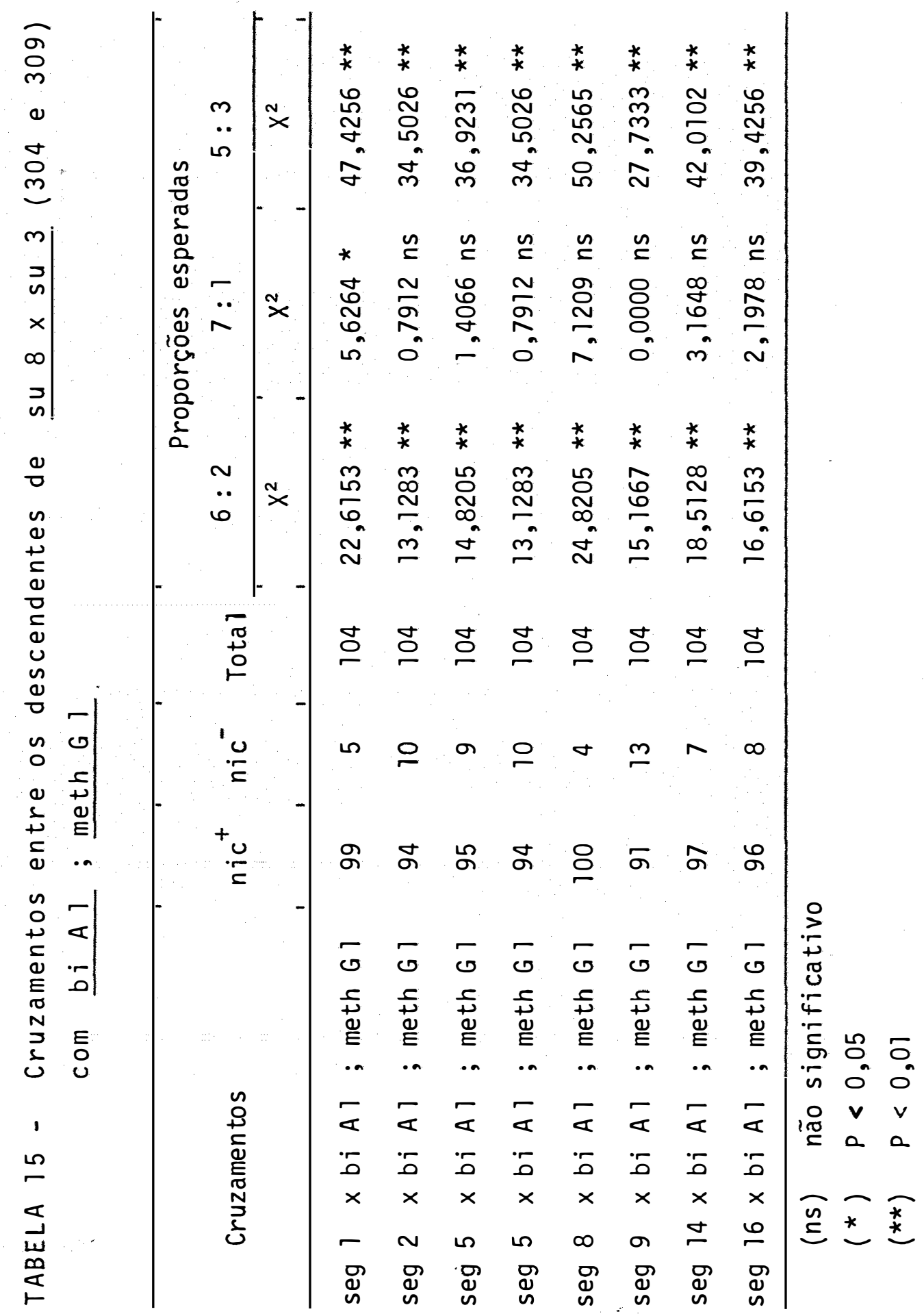




\section{5 - Heterocários e Diplóides entre Linhagens Provavelmen- te Portadoras de Dois Genes Supressores e a Linhagem MSE}

Foram realizados heterocārios e diplōides entre as linhagens segregantes dos cruzamentos que envolveram li nhagens com genes supressores e as linhagens ${ }^{n i c^{+}}$resultantes dos cruzamentos entre as linhagens com provavelmente dois supressores MSE e a linhagem. Todas essas linhagens apresentaram o fenōtipo $\underline{n i c}^{+}$por supressão e provavelmente algumas delas (escolhidas ao acaso) apresentavam dois supressores para a mesma deficiēncia.

Os heterocārios e diploides foram testados quan to a prototrofia para ácido nicotínico e os resultados obti dos encontram-se na Tabela 16. 
TABELA 16 - Heterocārios e diplóides entre linhagens provavelmente portadoras de dois genes supressores e a linhagem MSE

\begin{tabular}{|c|c|c|c|c|c|c|}
\hline & & & Heter & àrios & Dip & ides \\
\hline & & & $\mathrm{nic}^{+}$ & $\mathrm{nic}^{-}$ & $\mathrm{nic}^{+}$ & $\mathrm{nic}$ \\
\hline su 2 & $2 \times s u$ & $3(301)$ & & & & \\
\hline & seg & $2 / / M S E$ & + & + & + & + \\
\hline & seg: & $3 / / \mathrm{MSE}$ & + & + & + & + \\
\hline & seg 1 & $4 / / \mathrm{MSE}$ & + & + & + & + \\
\hline & seg $2 !$ & 5 // MSE & + & + & + & + \\
\hline su 2 & $2 \times s u$ & $3(304)$ & & & & \\
\hline & seg & $5 / / \mathrm{MSE}$ & + & + & + & + \\
\hline & seg & $8 / / \mathrm{MSE}$ & + & + & + & + \\
\hline & seg 1 & $5 / / \mathrm{MSE}$ & + & + & + & + \\
\hline & seg 20 & $033 \mathrm{mse}$ & + & + & + & + \\
\hline su 5 & $5 \times s u$ & $3(304)$ & & & & \\
\hline & seg & $1 / / \mathrm{MSE}$ & + & + & + & + \\
\hline & $\operatorname{seg} 1$ & $1 / / \mathrm{MSE}$ & + & + & + & + \\
\hline & seg 21 & $1 / 1 / \mathrm{MSE}$ & + & + & + & + \\
\hline & $\operatorname{seg} 23$ & $3 / / \mathrm{MSE}$ & + & + & + & + \\
\hline su 5 & $5 \times s u$ & $3(319)$ & & & & \\
\hline & seg & $4 / / M S E$ & + & + & + & + \\
\hline & seg 7 & $7 / / M S E$ & + & + & + & + \\
\hline & seg 13 & $3 / / \mathrm{MSE}$ & + & + & + & + \\
\hline & $\operatorname{seg} 2 \epsilon$ & $6 / / \mathrm{MSE}$ & + & + & + & + \\
\hline
\end{tabular}


TABELA 16 - Continuação

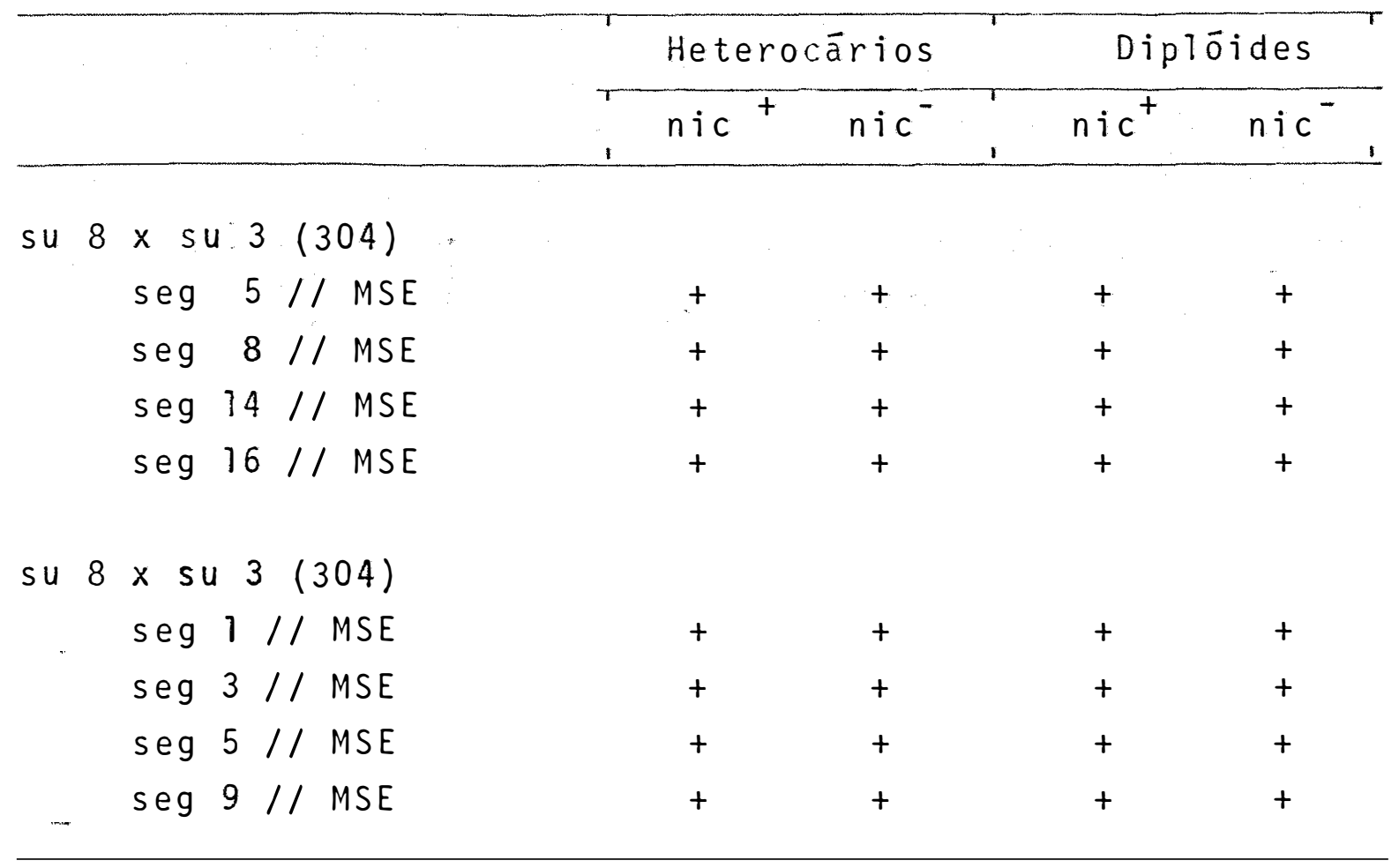




\section{5 - DISCUSSÃO}

\section{1 - Cruzamentos Controle}

os cruzamentos controle realizados entre as $1 \underline{i}$ nhagens contendo genes supressores e a linhagem pro A I ; paba A 6 ; yA2 tiveram as finalidade de confirmar os valores de ligação entre os genes supressores e o gene nic B 8 - que MIRAN DA FILHO (1972) obteve em seu trabalho. Da anālise dos resul tados da Tabela 4 podemos observar que os genes su 1 , su 3 , su 5 e su 8 são distais em relação ao gene nic B 8 ao passo que os genes su 2, su 4 e su 9 são proximais, o que vem a confirmar plenamente os resultados obtidos por MIRANDA FILHO (1972). Observou também esse autor que deveriam existir pelo menos quatro loci supressores, dos quais dois continham alelos mūitiplos. Os genes su 1 e su 3 foram mapeados num locus e 
$\underline{\text { su } 2}, \underline{\text { su } 4}$ e su 9 noutro. Em nossos resultados os valores de ligação entre os genes supressores analisados e o gene nic B 8 também confirmam os dados do referido autor.

MIRANDA FILHO (1972) observou que todos os supressores em estudo estavam localizados no mesmo grupo de ligação, o grupo VII, o que encerra o gene nic B 8 . Os resulta dos mostrados na Tabela 6 , relacionados à anālise mitótica de setores haplóides isolados a partir de diplóides obtidos nos heterocārios das linhagens MSE su nic B 8 com a linhagem pro. A 1 ; paba A 6 : yA 2 confirmam o fato de os genes supressores estarem localizados no mesmo grupo de ligação que contém o ge ne nic B 8 .

- MONTEIRO (1979) por sua vez, isolou mais sete supressores do mutante nic B 8 e observou que somente dois de les foram localizados no grupo de ligação VII. Dos demais ge nes isolados, dois foram localizados no grupo IV e um no grupo VI.

A anālise meiótica dos cruzamentos entre a linhagem MSE, e linhagens portadoras de genes supressores com a Iinhagem proA 1 ; paba A 6 ; yA 2 cujos resultados podem ser observados na Tabela 5 revela que a coloração das colónias é herdada independente dos genes supressores. Da mesma manei ra, a Tabela 7 apresenta a segregação de cada gene marcador. Todas as segregações mostraram ocorrer na proporção mendeliana simples de $1: 1$, confirmada pelo teste de $x^{2}$. 
Os resultados obtidos com o cruzamento das 1 inhagens bi A I ; meth G1 e yA2 ; nic A2 ; ribo D 5 observa dos na Tabela 8 mostram que os alelos que conferem prototro fia e auxotrofia para ácido nicotínico segregam na proporção mendeliana de $1: 1$.

Também como controle foram realizados heterocá rios e diplóides entre as linhagens com genes supressores e a linhagem pyro A 4 ; nic B 8. Heterocārios e diploides têm a finalidade de se avaliar a interação gênica quanto a domināncia e recessividade dos genes em estudo, porém os resultados da Tabela 9 nos mostram que tanto heterocários quando diplóides efetuados entre as linhagens acima referidas foram eficientes em crescer tanto em presença quanto em ausência de ácido nicotínico.

\section{2 - Testes de Especificidade}

A ação de especificidade gênica dos supresso :res em estudo, relativos ao gene nic $B$, foi ensaiada em re lação ao gene nic A 2 .

Como já foi observado o gene nic B 8 e seus su pressores foram localizados no grupo de ligação VII e o gene nic A2 foi mapeado no grupo de ligação $V$. Os supressores de nic B 8 poderiam suprimir o mutante nic A 2 se apresentassem uma ação não específica e para tanto a proporção de 1 nic ${ }^{\dagger}: 1$ 
nic ${ }^{-}$seria suficiente para explicar os resultados. Da mesma maneira, se apresetassem uma ação especiffica de supressão, is to $\bar{e}$, su nic B 8 só seria eficiente em suprimir o mutante nic B 8, a proporção de 5 nic : 3 nic $^{+}$seria apropriada para explicar os resultados.

os resultados mostrados na Tabela 10 indicam que os supressores do mutante nic B 8 foram incapazes de suprimir o mutante nic A 2. A proporção esperada de 5 nic $^{-}$: $3 \mathrm{nic}^{+}$foi apropriada para explicar os resultados obtidos, confirmada pelo teste de $x^{2}$.

Podemos sugerir que, de acordo com os resultados obtidos, os genes supressores em estudo do mutante nic B 8 são especîficos em sua ação e não suprimem o mutante nic A 2 .

Resultados semelhantes foram encontrados por TODD e CASSELTON (1973) ao verificarem que em Coprinus os ge nes acu-1 su ${ }^{+}$são especîficos em sua ação.

observaram tambēm que esses genes supressores, apresentam trēs propriedades que predizem ser supressores do tipo "missense" que especificam tipos de tRNA modificados com especificidades de codon alteradas. As mutaçöes "missense" são conseguidas por transiçoes ou transversões de bases na cadeia de DNA de modo a se alterar somente um aminoácido na cadeia protéica. A primeira dessas propriedades é que são alelo-específicos, isto $\bar{e}$, o gene $\underline{s u}^{+}$que suprime um alelo não conse gue suprimir outro alelo testado. Segundo, quando qualquer 
gene su $^{+}$è colocado em heterozigose num heterocārio ou diplói de, o efeito de supressão não se expressa ou se expressa de ma neira tão fraca que parece ser recessivo. Terceiro, quando dois genes su ${ }^{+}$diferentes são colocados num duplo heterozigoto, o efeito de supressão é mantido. A alelo-especificidade $\vec{e}$ tipica de supressores "missense".

BAL e colaboradores (1979) tambëm observaram que em Aspergizzus niduians que os supressores do mutante ad A 24 eram alelo-espeç̃ficos porëm eram locus não especĭfi$\cos$ e que são supressores do tipo "nonsense".

Dados semelhantes de supressores que mostraram ação não especiffica de supressão foram conseguidos por SHAH RIARI e CASSELTON (1973) em Coprinus. Estudando a mutação met 1 observaram que podia ser suprimida por cinco genes supressores recessivos diferentes.

A especificidade ou näo de genes supressores es tá relacionada a metabolismo da caracteristica em estudo.

os resultados obtidos neste trabalho nos permi tem sugerir que os mutantes nic B 8 e nic A 2 têm diferentes papeis quanto ao metabolismo do äcido nicotinico em Aspergiz tus nidutans. 


\section{3 - Comportamento de Dois Supressores Reunidos na Mesma LINHAGEM}

Foram efetuadas séries de cruzamentos entre li nhagens contendo genes supressores para a mesma deficiéncia na tentativa de se reunir dois deles na mesma linhagem.

A Tabela 11 mostra os resultados obtidos dos cruzamentos entre linhagens com genes supressores e o segre gante 13 cujo genōtipo é su 8 nic B 8 ; pyro A 4 ; paba A 6 .

Foram testadas duas proporções na hipótese de se haver dois supressores para a mesma deficiencia reunidos numa ūnica linhagem. A proporção de $6 \mathrm{nic}^{+}: 2 \mathrm{nic}^{-}$seria apropriada para explicar a manutenção do efeito de supressão en quanto que $4 \mathrm{nic}^{+}: 4 \mathrm{nic}^{-}$explicaria o efeito de cancelamento mütuo da supressão.

Da anālise dos resultados obtidos podemos concluir que a proporção de $6: 2$ e a que explica a maior parte dos cruzamentos, tendo seus resultados confirmados pelo teste de $x^{2}$. Os únicos dois resultados que mostraram $x^{2}$ significativo foram os cruzamentos que envolveram os supressores su ? e su 3 que são alelos múltiplos e que pelo fato de estarem ma peados muito próximos ao gene su 8 (ligados) teriam sua recom binação dificultada. Por outro lado, o nümero de colónias analisadas (153) era insuficiente para que surgissem entre elas os recombinantes desejados. 
Podemos observar tambēm que a proporção $4: 4$ testada apresenta $X^{2}$ significante $(P<0,01)$ em todos os cruzamentos analisados.

Estes resultados sugerem que, para o mutante nic B 8, a presença de dois supressores na mesma linhagem leva à manutenção do efeito de supressão.

Outros cruzamentos foram então efetuados para se verificar se realmente esse fenomeno se mantinha, ou seja, dois supressores para deficiência em àcido nicotînico, mantinham seu efeito de supressão quando reunidos na mesma linhagem.

Os resultados da Tabela 12 são semelhantes aos da Tabela 11. Alguns dos resultados dos testes da proporção $6: 2$ que envolveram o su 2 e su 4 mostraram $x^{2}$ significativo a nîvel de $5 \%$ porém năo significativos ao nível de $1 \%$ e poderiam ser explicados por alguma interferência na recombinação desses genes jā que não estão ligados.

o fato de os resultados de testes que envolveram os supressores su 3 e su 8 terem dado resultados de " $x^{2}$ significativos podem ser perfeitamente explicados por ausén cias de permutas entre esses supressores, visto estarem ligados.

Podemos observar também que para a proporção de $4: 4$ os resultados todos dos testes de $x^{2}$ foram significativos a nível de $1 \%$. 
Estes resultados nos permitem novamente sugerir o efeito de manutenção de ação de supressão quando doịs supres sores para uma dada deficiência estão reunidos na mesma linha gem.

Para se pesquisar, então, a presença de dois su pressores numa mesma linhagem entre os segretantes que exibiam fenōtipo nic dos cruzamentos cujos dados constam da Tabela 12 foram cruzados com a linhagem bi A I ; meth GI (de fenötipo $\left.\underline{n i c^{+}}\right)$.

Três proporções foram então testadas. A proporção 6 nic $^{+}: 2$ nic $^{-}$è apropriada para pesquisar a presença de um supressor nas linhagens testadas. A proporção $7 \mathrm{nic}^{+}$: 1 nic $^{-}$ë apropriada para explicar a manutenção do efeito de supressão quando dois supressores estão reunidos na mesma 1 inhagem e a proporção $5 \mathrm{nic}^{+}: 3 \mathrm{nic}^{-}$quando esses dois supressores cancelam-se mutuamente.

Os resultados mostrados pelas Tabelas 13,14 e 15 ressaltam que a proporção $7 \mathrm{nic}^{+}: 1 \mathrm{nic}^{-}$apresentou resul tados de $x^{2}$ não significativos em quase todos os cruzamentos. As excessões poderiam ser explicadas por algum problema de re combinação como nos casos dos segregantes 15 da Tabela $13 ; 4$ da Tabela 14 e 1 da Tabela 15 que foram significativos para as três proporções testadas (genes ligados).

Os resultados dos testes que envolveram a proporção $6: 2$ apresentaram $x^{2}$ significativo em todos os casos 
analisados, assim como a proporçao $5: 3$. No entanto para as Tabelas 14 e 15 que envolvem os supressores su 5 e su 8 respectivamente tais resultados podem ser explicados devido ao fato de esses supressores serem 1 igados a o supressor su 3.

Todavia os resultados sugerem a manutenção do efeito de supressão quando dois supressores para a mesma defi ciència estäo reunidos numa 1 inhagem.

Tais não foram os resultados de GILMORE (1967) que observou que a reunião de dois supressores para a mesma de ficiência em uma linhagem de saccharomyces cerevisiae produzia cēlulas aberrantes e de crescimento retardado.

TODD e CASSELTON (1973) observaram que em Coprinus havia infertilidade nos cruzamentos entre linhagens por tadoras de genes supressores para a mesma deficiēncia. 0 mes mo fenōmeno foi observado por SEALY-LEWIS e CASSELTON (1977), estudando supressores do gene met em Coprinus.

BAL e colaboradores (1979) estudando os supressores para a deficiēncia em adenina em Aspergizzus niduzans tambēm não tiveram sucesso em cruzar linhagens contendo dois supressores.

Em nossos experimentos sugerimos o efeito de ma nutenção de supressão, embora se tenha necessitado efetuar de zenas de cruzamentos até se conseguir resultados satisfatórios. Pudemos notar que a presença de um gene supressor tende a diminuir a fertilidade dos cruzamentos. Porém, estudos ainda 
devem ser efetuados para que se venha confirmar a hipótese.

Foram tambëm realizados heterocários e diplói

des entre as linhagens provavelmente portadoras de dois genes supressores e a linhagem MSE. Os resultados obtidos e mostra dos na Tabela 16 evidenciam que tanto heterocários quanto diplóides cresceram em ausēncia de ácido nicotínico e que pro vavelmente alguns dos segregantes continham dois supressores, reunidos na mesma linhagem e mantido o efeito de supressão.

\section{4 - 0 Mecanismo de Acão dos Supressores}

0 mecanismo de regulação da ação gēnica conhecido por "sistema de regulação em cascata" proposto por PONTECORVO (1963), foi sugerido por MIRANDA FILHO (1972) e AZEVE Do (1974) para explicar o modo de ação dos genes supressores nic B8 das linhagens utilizadas neste trabalho. 0 mesmo sistema foi utilizado por MENEZES (1974), citada por MONTEIRO (1979), para explicar o modo de ação dos genes supressores de variantes deteriorados em Aspergizzus niduzans. 
Neste sistema de regulação, dois repressores es tão envolvidos como reguladores da ação gênica. Nas linhagens selvagens, um dos repressores, designado repressor $R_{2}$, tem a capacidade de interagir com os genes estruturais impedindo-os de produziremo mRNA que conduz a sintese de proteinas. o outro repressor, designado $R_{1}$, interfere. com a ação do repressor $R_{2}$ bloqueando sua ação e portanto incorrendo no funcionamento normal dos genes estruturais. Segundo MIRANDA FilHo (1972) o mutante nic B8 corresponderia a uma mutação no locus responsāvel pela produção do repressor $R_{1}$ e os supressores se riam mutações nos loci responsāveis pela produção dos repressores $R_{2}$. A mutação supressora no repressor $R_{2} i m p e d e-0$ de produzir o repressor, havendo consequente transcrição normal do mRNA e, portanto, produção de proteínas.

Uma representação esquemātica desse sistema é apresentado na Figura 2.

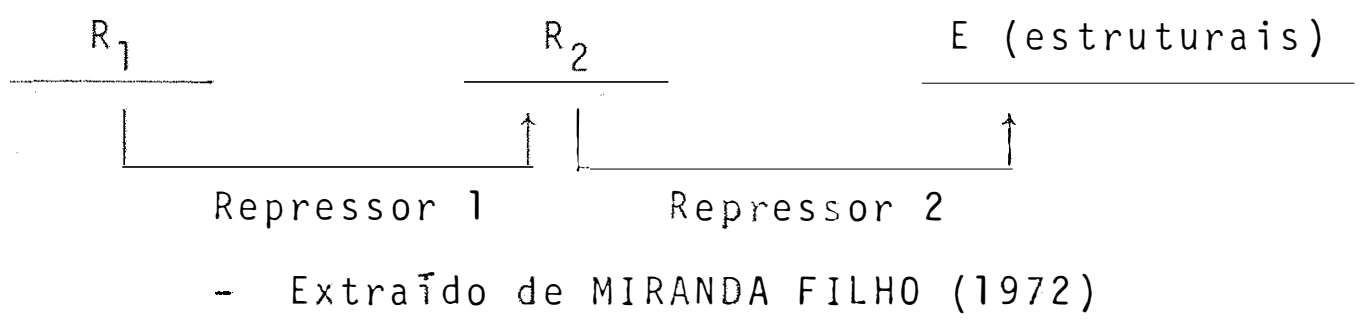

FIGURA 2 - Sistema de regulação em cascata (PONTECORvo, 1963) 
MONTEIRO (1979) sugere um sistema alternativo do sistema proposto por MIRANDA FILHO e AZEVEDO (1974) para ex plicar a ação de genes supressores do mutante nic B8. Neste sistema proposto, o produto gènico do supressor atua como corepressor que, juntamente com o repressor produzido pelo 10cus $R_{1}$ de sintese de ácido nicotinico, formam um complexo repressor que bloqueia a ação dos genes estruturais. Vários su pressores nic B8 evidenciaram capacidade de interferir no me canismo de sintese do tiossulfato de södio, quer seja positivamente, quer seja negativamente.

A Figura 3 ilustra este aspecto.
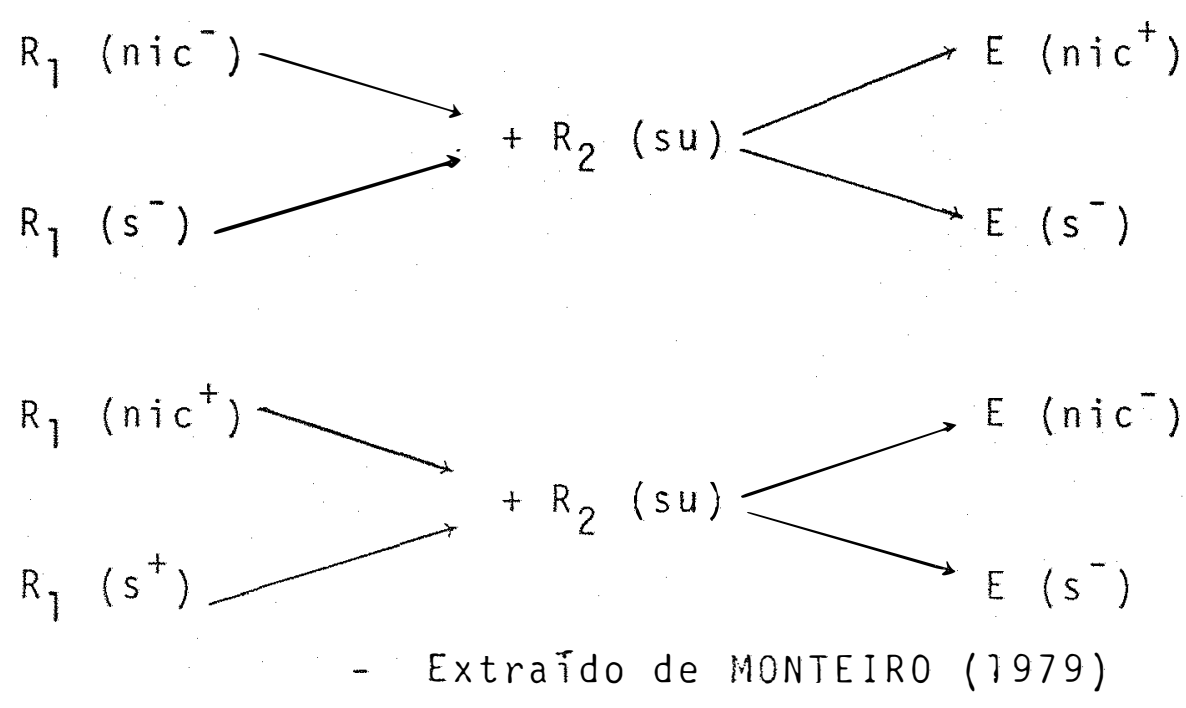

FIGURA 3 - Sistema alternativo de regulação em cascata

Os nossos resultados podem ser perfeitamente ex plicados pelo sistema de regulação em cascata proposto por PON 
TECORVO (1963) e utilizado por MIRANDA FILHO e AZEVEDO (1974) para explicar a ação dos supressores do mutante nic B8.

TODD e CASSELTON (1973) postulam que a manuten ção do efeito de supressão quando dois supressores para a mes ma deficiēncia são reunidos na mesma linhagem ē uma das carac terísticas de supressores missense. Trabalhando com os mutan tes acu I de Coprinus que leva à incapacidade de crescimento em acetato como ünica fonte de carbono, observam que o meca nismo de supressão desses genes está relacionado a tipos modí ficados de tRNA, isto é, alterando a especificidade do codon. A mutação poderia ocorrer no gene estrutural que codifica o tRNA ou poderia ocorrer noutro gene e levā-lo a perda de função de algumas enzimas que modifica o tRNA.

CASSELTON e SHAHRIARI (1975) observaram que a ação dos supressores do mutante met-1-1 em Coprinus também es tā relacionada a alterações no tRNA.

CASSELTON (1979, comunicação pessoal) sugere que a ação dos supressores do mutante nic B8 também deve estar relacionada a estruturas alteradas de moléculas de tRNA.

Da anālise de nossos dados podemos propor a hi pótese de que os supressores do mutante nic B8 sejam do tipo missense e que envolvam ação de tRNA. Estas alterações poderiam ser tanto nos genes estruturais que codificam esses tRNA bem como a nỉvel de transcrição ou tradução da informação gēnica. 
79 .

A reunião de dois supressores para a mesma deficiência na mesma linhagem não envolveria competição de tRNA de modo que a ação supressão seria mantida.

A reunião das hipóteses da regulação em cascata e da que envolve tRNA alterados seria uma tentativa a mais de se explicar o modo de ação de genes supressores do mutante nic B8.

E óbvio que estudos mais acurados desses aspec tos e novos estudos envolvendo o mecanismo de ação gênica além de trazer novos tópicos para estudos trarão tambēm novas luzes sobre os mecanismos de ação da supressão gênica e a somatória do conhecimento acumulado tem sido o substrato do desenvolvimento da Genética e da Biologia em geral. 
80.

\section{6 - CONCLUSÕES}

Os resultados obtidos neste trabalho e que foram objeto de discussão no item anterior proporcionaram uma sērie de informações dadas a seguir:

a - Os genes supressores do mutante nic B 8 analisados neste trabalho mostraram-se específicos na sua ação de supressão. Isto quer dizer que são gene-específicos e foram incapazes de suprimir o mutante nic A2.

b - A reunião de dois supressores para a mesma deficiēncia em uma única linhagem sugere manter o efeito de supres são.

c - 0 efeito de manutenção da ação de supressão quando dois supressores para a mesma deficiência são reunidos numa mesma linhagem é tîpico de supressores "missense" e sugeri mos que os genes supressores do mutante nic B8 das linha gens utilizadas neste trabalho sejam supressores"missense". 
81.

d - 0 modo de ação dos supressores, relacionados com o mecanismo da regulação da sintese de ácido nicotīnico, foi explicado com base no sistema de regulação em cascata pro posto por PONTECORVO (1963) bem como foi sugerida a hipotese de, além da regulação em cascata, estejam envolvi dos tambēm tRNA de estrutura alterada. Estas alterações poderiam ocorrer tanto nos genes estruturais que codificam essas tRNA como a nível de transcrição ou tradução da informação genētica. 
82.

\section{7 - LITERATURA CITADA}

APIRION, D., 1962. A general system for the automatic selec tion of auxotrophs from prototrophs and vice-versa in microorganisms. Nature, (London), 195: 959-961.

AYLING, P. D., 1969. Methionine suppressors in Aspergizzus nidulans: their genetics and behaviour in heterokaryons and diploids. Genetical Research (Camb.), 14: 275-289.

AZEVEDO, J.L., 1973. Isolamentos de mutantes auxotróficos em fungos. In: AZEVEDO, J. L. e S. O. P. DA COSTA, ed. Exercícios Präticos de Genética São Paulo, Companhia Editora Nacional, $288 \mathrm{p}$.

AZEVEDO, J. L. ; A. OLIVEIRA e A. J. ROCHA CAMPOS, 1976. Re plicador multifio para transferéncia de esporos de fungos filamentosos. Summa Phytopathologica, 2 : 237-241. 
AZEVEDO, J.L. e E. P. SANTANA, 1975. The use of chloroneb to obtain haploid segregants from heterozygous diploids of Aspergizzus niduzans. Aspergillus News Letter, 13: 6 .

BARACHO, I. R. ; R. VENCOVSKY e J. L. AZEVEDO, 1970. Correlation between size and hybrid and selfed state of cleisto thecia in Aspergizzus niduzans. Transactions of the British Mycological Society, 54(1): 109-116.

BAYLISS, F. T. e R. T. VINOPAL, 1971. Selection of ribossomal mutants by antibiotic suppression in yeast. Science. 174: $1339-1341$.

BERG, P.; C. YANOFSKY e J. CARBON, 1967. Missense suppression do to a genetically altered RNA. Cold Spring Harbour Symposia on Quantitative Biology, 31: 487-497.

BISWAS, D. K. e L. GORINI, 1972. Restriction, de-restriction and mistranslation in missense suppression. Ribossomal discrimination of transfer RNA. Journal of Molecular Biology, 64: 119-134.

BONNER, D. M., 1951. Gene-enzyme relationship in Neurospora. Cold Spring Harbour Symposia on Quantitative Biology, 16 : $143-157$.

BORDIGNON OLIVEIRA, L. M. M., 1978. Resistēncia à arginina em linhagens deficientes para a sintese de lisina em Asper gizzus niduzans. Dissertação apresentada a ESALQ/USP para obtenção do tîtulo de Mestre. 116 p. Piracicaba, São Pau 10 . 
BRENNER, S. e J. R. BECKWITH, 1965. Ochre mutants, a new class of suppressible nonsense mutants. Journal of Molecular Biology, 13: 629-637.

BRODY, S. e C. YANOFSKY, 1963. Suppressor gene alteration of protein primary structure. Proceeding of National Academy of Sciences. USA, 50: 9-16.

CAMPBELL, A., 1963. Fine structure genetics and its relation to function. Annual Review of Microbiology, 17: 49-60.

CARBON, J. ; P. BERG e C. YANOFSKY, 1966. Studies on Missen se suppression of the tryptophan synthetase A: protein mutant A36. Proceedings of National Academy of Sciences, USA, 56: 764-771.

CARBON, J. e J. B. CURRY, 1968. Genetically and chemically derived missense suppression transfer RNAs with altered enzymic aminoacylation rates. Journal of Molecular Biology, 38: 201-216.

CASSELTON, L. A., 1971. Suppressor genes. Science Progress (0xford), 59: 143-160.

CASSELTON, L. A. e H. SEALY LEWIS, 1976. Restauration of enzyme activity by recessive suppressor gene mutation in Coprinus. Heredity, 37(1): 154-155.

CASSELTON, L. A. e H. SHAHRIARI, 1973. Complementation and allele specificity as tests of suppressor gene mechanisms in a fungus. Genetics, $74(2): 39$. 
CASSELTON, L. A. e H. SHAHRIARI, 1975. Suppression of methionine mutants in Coprinus. II functional suppressors of methionine mutations. Molecular and General Genetics, 138(1): $33-40$.

CHALMERS, Jr. J. H. e T. W. SEAK, 1971. Supersuppressible mutants in Neurospora: mutants at the tryp 1 and tryp 2 loci affecting the structure of multienzyme complex in the tryptophan pathway. Genetics, 67: 353-363.

CHANG, T. S., 1972. Genetic studies of a dome mutant and its suppressor gene in Schizophyzum commune. Australian Journal of Biological Science, 25(4): 757-764.

CHILDS, J. D., 1967. Genetic analyses of suppressors of me thionine mutants of Salmonezza typhimurium. Heredity, 22: $425-434$.

CLUBERTSON, M. R. ; L. CHARNAS; M. T. JONHSON E G. R. FINK, 1977. Frameshift and frameshifts suppressors in Saccharomyces cerevisiae. Genetics, 86(4): 745-764.

CLUTTERBUCK, A. J., 1973. Gene symbols in Aspergizzus nidu Zans. Genetical Research (Camb.), 21: 291-296.

CLUTTERBUCK, A. J., 1974. Aspergizlus niduZans. In: KING, R. C. ed. Handbook of Genetics. New York and London, Plenum Press, I: 447-510.

COPPIN-RAYNAL, E., 1977. Ribossomal suppressors and antis suppressors in Podospora anserina, Resistance to cyclohe ximide. Journal of Bacteriology, 131(3): 876-883. 
Cox, B. S., 1971. A recessive lethal super-supressor mutation in yeast and other psi phenomena. Heredity, 26: 211232 .

Cox, B. S., 1977. Allosuppressors in yeast. Genetical Research (Camb.), 30(2): 187-206.

CRICK, F. H. C. ; L. BARNETT; S. BRENNER E R. J. WATTS-TOBIN, 1961. General nature of the genetic code for proteins. Nature, (London), 192: 1227-1232.

DAVIS, R. H., 1961. Suppression of pyrimidine 3 mutants of Neurospora and its relation to arginine synthesis. Science, 134: 470-471.

DAVIS, R. H., 1962. Consequences of a suppressor gene effective with pyrimidine and proline mutants of Neurospora. Genetics, 47: 351-360.

DORN, G. L., 1967. A revised map of the eight linkage group of Aspergizzus niduzans. Genetics, 56: 619-620.

ELSEVIERS, D. e L. GORINI, 1975. Direct selection of mutants restricting efficiency of suppression and misreading levels in Escherichia coli B. Molecular and General Genetics, 137: $277-287$.

ESSER, K. e U. STAHL, 1973. Monokaryotic fruiting in the basidiomycete Polyporus ciliatus and its suppression by incompatibility factors. Nature, 244(5414): 304-305. 
FARMER, J.L., 1977. An allele-specific suppressor of whitecoral in Drosophiza melanogaster. Heredity, 39(2): 297303 .

GAJEWSKI, W. e J. LITWINSKA, 1968. Methionine 1oci and their suppressors in Aspergizzus nidulans. Aspergillus News. Letter, 8: 9-10.

GARVIN, R. T. e I. GORINI, 1975. A new gene for ribossomal restriction in Escherichia coli. Molecular and General Genetics, 137: 73-78.

GILES, N. H., 1951. Studies on the mechanism of reversion in biochemical mutants of Neurospora. Cold Spring Harbour Symposia on Quantitative Biology, 16: 283-313.

GILES, N. H. e C. W. H. PARTRIDGE, 1953. The effect of a suppressor on allelic inositolless mutant in Neurospora crassa. Proceeding of National Academy of Sciences, USA, 39: $479-488$.

GIRARD, J. e J.L. ROSSIGNOL, 1974. The suppression of gene conversion and intragenic crossing-over in Ascobolus immer sus: evidence for modifiers acting in the heterozygous state. Genetics, 76(2): 221-243.

GORINI, L., 1970. Informational Suppression. Annual Review of Genetics, 4: 107-134.

GORINI, L., 1973. The role of the ribosome in controlling translational fidelity. Heredity, $31(10): 420$. 
GORINI, L., 1974. Streptomycin and misreading of the geneticcode. Ribosomes. Cold Spring Harbour Laboratory, pp. 791 .

GORINI, L. e J. R. BECKWITH, 1966. Suppression. Annual Review of Microbiology, 20: 401-422.

GUPTA, N. K. e H. G. KHORANA, 1966. Missense suppression of the tryptophan synthetase A - protein mutant A-78. Proceedings of National Academy of Sciences, USA, 56: $772-779$.

HARTMAN, P. E. e J.R. ROTH, 1973. Mechanisms of suppression. In: CASPARI, E. W., ed. Advances in Genetics, 17: $1-105$.

HAWTHORNE, D. E.- U. LEUPOLD, 1974. Suppressors in yeast. Current Topics in Microbiology and Immynology, 64: 1-49.

HILL, C.W. ; J. FOULDS; L. SOLL e P. BERG, 1969. Instability of a missense suppressor resulting from a duplication of genetic material. Journal of Molecular Biology, 39: $563-581$.

HOULAHAN, M. B. e H. K. MITCHELL, 1947. A suppressor in Neurospora and its use as evidence for allelism. Proceedings of National Academy of Sciences, USA, 33: 223-229.

HOWARTH, S., 1958. Suppressor mutations in some cystine requiring mutants of salmonezza typhimurium. Genetics, 43: 404-418. 
KÄFER; E., 1961. The presence of spontaneous recombination in vegetative nuclei of Aspergizzus nidulans. Genetics, 46: $1581-1609$.

KOHOUT, J. e H. BERTRAND, 1976. Nuclear suppressors of the "poky" cytoplasmic mutant in Neurospora crassa. I. Gene tics and respiratory properties. Canadian Journal of Genetics and Cytology, 18(2): 311-324.

KOLTIN, Y. e P. R. DAY, 1976. Suppression of the Killer phenotype in Ustizago maydis. Genetics, 82(4): 629-637.

LEIN, J. e P. S. LEIN, 1952. Studies on a suppressor of nonallelic acetate - requirement mutants of Neurospora. Proceedings of National Academy os Sciences, USA, 38: 44-48.

LEWIS, S., 1961. Genetic analysis of methionine suppressors in Coprinus Zagopus. Genetical Research. (Camb.), 2: 141155 .

LEWIS, D. e L. A. CASSELTON, 1975. Missense suppression in Coprinus Zagopus associated with a chromosome duplication. Journal of General Microbiology, 88(1): 20-26

LILLY, J. L., 1963. A possible technique for the simultaneous measurement of forward mutation rate in several cistrons. Aspergillus News Letter, 4 : 18.

McCREADY, S. e B. COX, 1973. Antisuppressors in yeast. Molecular and General Genetics, 124(4): 305-320.

MCCREADY, S. e B. COX, 1976. Suppressor-specificity of anti suppressors in yeast. Genetical Research. (Camb.), 28(2): $129-138$. 
MCCULLY, K. S. e E. FORBES, 1965. The use of p-fluorophenyl alanine with "master strain" of Aspergizzus niduzans for assigning genes to linkage groups. Genetical Research (Camb.), 6 : 352-359.

MILLS, D. I. e A. H. ELLINGBOE, 1969. The induction and cha racterization of recessive suppressor of arg-2 in Schizo phyzzum commune. Molecular and General Genetics, 104: $313-320$.

MITCHELl, I. G. e E. A. BEVAN, 1974. Suppressors of "blue" mutations in yeast. Genetical Research (Camb.), 23: 3745 .

MITCHELL, M. B. e H. K. MITCHELL, 1952. Observation on the behaviour of suppressors in Neurospora. Proceedings of National Academy of Sciences, USA, 38: 205-214.

MIRANDA FILHO, J. B., 1972. Supressores do mutante nic 8 em Aspergizzus niduzans. Dissertação apresentada à ESALQ/USP para obtenção do tỉtulo de Mestre. 83 p. Piracicaba, S. Paulo.

MIRANDA FILHO, J. B. e J. L. AZEVEDO, 1974. Nicotinic acid suppressors in Aspergizzus niduzans. Experientia (Basel) 30(4): $356-358$.

MONTEIRO, A. C., 1979. Isolamento e caracterização genética de supressores do mutante nic B8 em Aspergizzus niduzans. Dissertação apresentada à ESALQ/USP, para obtenção do títú 10 de Mestre, 145 p. Piracicaba, S. Paulo. 
MORGAN, D. H., 1966. Suppression of "purple" in Coprinus la gopus - an anomalous genetic situation. Genetical Research (Camb.), 7: 195-206.

NEWCOMBE, K. D. e A. J. F. GRIFFITHS, 1973. The suppression of ad-3B mutants by supersuppressors in Neurospora crassa. Genetics, 75: 615-622.

PICARD, M., 1973. Genetic evidence for a policistronic unit of transcription in the complex locus 14 in Podospora anse rina: II. Genetic analysis of informational suppressors. Genetical Research, 21(1): 1-15.

PICARD-BENNOUN, M., 1976. Genetic evidence for ribossomal anti-suppressors in Podospora anserina. Molecular and. General Genetics, 147(3): 299-306.

PIOTROWSKA, M. ; M. SAVICKI e P. WEGLENSKI, 1969. Mutants of the arginine-proline pathway in Aspergizzus niduzans. Journal of General Microbiology, 55: 301-305.

PONTECORVO, G., 1963. Microbial genetics retrospect and prospect. Proceedings of the Royal Society of Biology, 158: $123-146$.

PONTECORVO, G. ; J. A. ROPER; L. M. HEMMONS ; K. D. MACDONALD e A. W. J. BUFTON, 1953. The genetics of Aspergizlus nidulans. Advances in Genetics, 5: 141-238.

REISSIG, J. L., 1963.a. Induction of forward mutants in the pyr-3 region of Neurospora. Journal of General Microbio logy, 30: $317-325$. 
REISSIG, J. L., 1963.b. Spectrum of forward mutants in the pyr-3 region of Neurospora. Journal of General Microbio logy, 30: $327-337$.

ROPER, J. A., 1952. Production of heterozygous diploids in filamentous fungi. Experientia, 8: 14-15.

ROTHWELL, M. A. e M. H. L. GREEN, 1973. Non-sense suppressors with unusual properties. Heredity, 31(1): 138.

RYCE, S. ; J. ATKINS e C. HUSSEY, 1973. Suppressors (UGA) wich also suppress frameshift mutations. Heredity, 31(1): 420 .

SADGOPAL, A., 1968. The genetic code after the excitement. Advances in Genetics, 14: 325-404.

SEALY-LEWIS, H. e L. A. CASSELTON, 1976. Dominant and reces sive suppressor genes of a met-5 mutation in Coprinus. Heredity, 37(1): 155 .

SEALY-LEWIS, H. e L. A. CASSELTON, 1977. Dominant and reces sive informational suppressors of a missense mutation in Coprinus. Molecular and General Genetics, 151(2): 189195.

SHAHRIARI, H. e L. A. CASSELTON, 1973. Bypass and translational suppressors of a methionine mutant in the fungus Coprinus lagopus. Heredity, 3](1): 137. 
SHAHRIARI, H. e L. A. CASSELTON, 1974. Suppression of methionine mutants in Coprinus: I. Complementation and allele specificity as criteria of suppressor gene action. Molecular and General Genetics, 134(1): 85-92.

STADLER, D. R., 1967. Suppressors of aminoacid uptake mutants in Neurospora. Genetics, 57: 935-942.

TODD, N. K. e L. A. CASSELTON, 1972. Non-complementation between recessive suppressor gene mutations in Coprinus 2 a gopus. Heredity, 28(2): 274.

TODD, N. K. e L. A. CASSELTON, 1973. Non complementation and recessiveness as properties of missense suppressor genes in the fungus Coprinus. Journal of General Microbiology, 77 (1): $197-207$.

WAGNER, R. P. e H. K. MITCHELL, 1955. Genetics and metabolism. New York, John Wiley and Sons, Inc., London, Chap man and Hall, Limited, l. ed., $444 \mathrm{p}$.

WAGNER, R. P. e H. K. MITCHELL, 1964. Genetics and metabolism. New York, London and Sidney, John Wiley and Sons, Inc., 2! ed., $673 \mathrm{p}$.

WARR, J.R. e J. A. ROPER, 1965. Resistance to variou inhibitours in Aspergizzus niduzans. Journal of General Mi crobiology, 40: 273-281.

WEGLENSKI, P., 1966. Genetical analysis of proline mutants and their suppressors in Aspergizzus niduzans. Genetical. Research (Camb), 8 : $317-321$. 
WEGLENSKI, P., 1967. The mechanism of action of proline suppressors in Aspergizzus niduzans. Journal of General Microbiology, 47: 77-85.

WITKIN, E. M., 1969. Ultraviolet-induced mutation and DNA repair. Annual Review of Genetics, 3: 525-552.

YANOFSKY, C. e P. St. LAWRENCE, 1960. Gene action. Annual Review of Microbiology, 14: $311-340$.

YOUNG, C. H. S. E B. S. COX, 1971. Enhanced observation of nonsense suppressor mutation frequency. Heredity, 27(3): 483 .

YOURNO, J. D. e S. R. SUSKIND, 1964.a. Suppressor gene action in the tryptophan synthetase system of Neurospora crassa: Genetic studies. Genetics, 50: 803-816.

YOURNO, J. D. e S. R. SUSKIND, 1964.b. Wild-like enzyme in a suppressed trutophan synthetase system of Neurospora crassa: Biochemical studies. Genetics, 50: 817-828.

YUILL, E., 1939. Two new Aspergizzus mutants. Journal of Botany, 77: 174-175. 